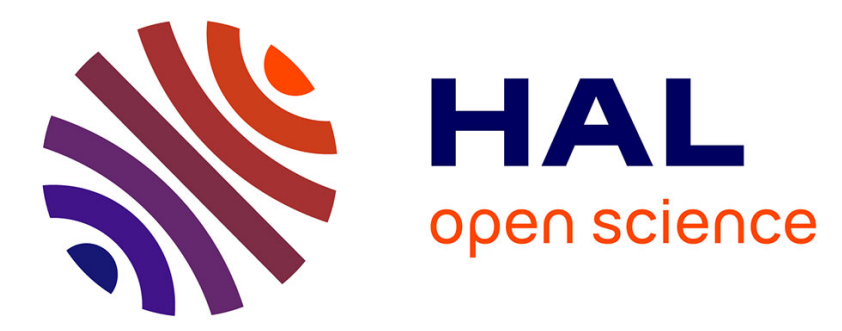

\title{
Geochemistry of the Lake Chad Tributaries Under Strongly Varying Hydro-climatic Conditions
}

A. Mahamat Nour, C Vallet-Coulomb, Camille Bouchez, P. Ginot, J. Doumnang, F. Sylvestre, P. Deschamps

\section{- To cite this version:}

A. Mahamat Nour, C Vallet-Coulomb, Camille Bouchez, P. Ginot, J. Doumnang, et al.. Geochemistry of the Lake Chad Tributaries Under Strongly Varying Hydro-climatic Conditions. Aquatic Geochemistry, Springer Verlag, 2020, 26 (1), pp.3-29. 10.1007/s10498-019-09363-w . insu-02407139

\section{HAL Id: insu-02407139 \\ https://hal-insu.archives-ouvertes.fr/insu-02407139}

Submitted on 21 Feb 2020

HAL is a multi-disciplinary open access archive for the deposit and dissemination of scientific research documents, whether they are published or not. The documents may come from teaching and research institutions in France or abroad, or from public or private research centers.
L'archive ouverte pluridisciplinaire HAL, est destinée au dépôt et à la diffusion de documents scientifiques de niveau recherche, publiés ou non, émanant des établissements d'enseignement et de recherche français ou étrangers, des laboratoires publics ou privés. 
Abstract

The Lake Chad Basin (LCB) is one of the main endorheic basins in the world and has undergone large level and surface variations during the last decades, particularly during the Sahelian dry period in the 1970s and the 1980s. The Chari-Logone River system covers $25 \%$ of the LCB but accounts for up to $82 \%$ of the Lake Chad water supply. The aim of this study is to investigate

\title{
Geochemistry of the Lake Chad tributaries under strongly varying hydro-climatic conditions
}

\author{
Mahamat Nour A. ${ }^{1,2}$, Vallet-Coulomb C. ${ }^{1}$, Bouchez C. ${ }^{1,4}$, Ginot P. ${ }^{3}$, Doumnang J.C. ${ }^{2}$, Sylvestre F. ${ }^{1}$, Deschamps P. ${ }^{1}$ \\ ${ }^{1}$ Aix Marseille Université, CNRS, IRD, Collège de France, INRA, CEREGE, Aix-en-Provence, France \\ ${ }^{2}$ Université de N'Djaména -Laboratoire HydroGéoscience et Réservoir, N'Djaména, Tchad \\ ${ }^{3}$ Université Grenoble Alpes, IRD, CNRS. Institut des Géosciences de l'Environnement, UMR5001, Grenoble, France \\ ${ }^{4}$ Univ Rennes, CNRS, Géosciences Rennes, UMR 6118, 35000 Rennes, France. \\ Email: $\underline{\text { mahamatnour@univ-ndj.td }}$
}

the dissolved phase transported by the Chari-Logone system, in order (i) to elucidate the origin and the behavior of major elements and the weathering processes in the watershed; (ii) to estimate the total dissolved flux, its variability over the last decades and the driving factors. To do so, samples were collected monthly between January 2013 and November 2016 at three representative sites of the basin: in the Chari River in "Chagoua", in the Logone River in "Ngueli" just before the confluence of both rivers, and at a downstream site in "Douguia", 30 $\mathrm{km}$ after the confluence. Concentrations in major elements displayed significant seasonal variations in the Chari and Logone waters. At the seasonal time scale, the comparison between the concentrations of chemical elements and the flow rates showed a hysteresis loop. This hysteresis behavior correspond to a variable contribution over time of two water bodies, fast surface water, and slow groundwater, the latter carrying higher concentrations and $\mathrm{Ca} / \mathrm{Na}$ ratio, which may result from the contribution of pedogenic carbonate weathering to the dominant signature of silicate weathering. On the other hand, similar average concentrations are observed in the Chari and Logone rivers, despite contrasted annual runoff. In addition, an interannual stability of ionic concentrations was observed in the Chari-Logone river during the flood regime, both during the years covered by our monitoring (2013-2016) and during the predrought period (1969, 1972 et 1973). This situation corresponds to a chemostatic behavior, where the annual river discharge is the main factor controlling the interannual variation of chemical fluxes.

Keywords: Lake Chad basin, chemical fluxes, silicate weathering, strontium 


\section{Introduction}

41 Located at the southern edge of the Sahara, in the central Sahel, Lake Chad is a large freshwater body that provides resources for 49 million people living around. This lake has a long history of alternating wet and dry periods spanning from millennia to the annual and seasonal time scales (Schuster et al. 2005; Sylvestre 2014). The high variability of the lake level, and associated lake extension, reflects its high sensitivity to climatic conditions, mainly due to its endorheic context. Located in the southern part of the Lake Chad Basin (LCB), the Chari Logone River system is today the only active hydrological catchment. It represents $25 \%$ of the total LCB surface, but accounts for up to $82 \%$ of the Lake Chad water supply (Bouchez et al. 2016). Therefore, as Lake Chad is the outlet of elemental fluxes carried by the Chari-Logone River, understanding its hydro-geochemical behavior and what control these fluxes is crucial to better characterize the chemical evolution of the lake.

River geochemistry reflects the various weathering processes that affect the Earth's surface (e.g. Probst et al. 1992; Louvat and Allègre 1997; Viers et al. 2000; Meybeck 2003; Ollivier et al. 2010; Chorover et al. 2017; Koger et al. 2018). Among the numerous studies that aimed at quantify weathering rates and understanding the parameters that control their variations, special attention was paid to silicate weathering, which, while pumping atmospheric $\mathrm{CO}_{2}$, plays a particular role in the global carbon cycle (e.g. Gaillardet et al. 1999; Amiotte Suchet et al. 2003; Hartmann et al. 2009; Mortatti \& Probst 2003).

Tropical environments occupy nearly a third of the total area of the continents; but they are under-represented in regional geochemical studies. Especially in Tropical Africa, only a few studies have focused on such geochemical processes i.e. weathering. The only African basins that have been investigated are those of Congo (Probst et al. 1992; Négrel et al. 1993), Nyong

63 (Viers et al. 2000), Niger (Picouet et al. 2002), South Africa (Meybeck et al. 1996) and 64 Sassandra (Agri et al. 2010). These studies have estimated weathering fluxes generally below 65 the world average rate. However, tropical environments are expected to encounter large hydrological perturbations in the coming decades with unknown consequences on weathering

\section{7 fluxes.}

68 From Sahel band, very few studies have been carried out and especially on the Chari-Logone 69 River system, which is one of the main water networks. Roche (1980) provided the first 70 observations describing the water physico-chemistry of Chari and Logone. Carmouze (1976) 71 and Gac (1980) also studied the transport of salt, in order to describe the lake's chemical 
equilibrium and to identify the mechanisms that regulate it. But since these early works, no significant study has attempted to characterize the dissolved load of the Chari-Logone system. The aim of the present study was to characterize the weathering processes that control the chemical load and fluxes towards Lake Chad, and to analyze their link with climate variations. Monthly sampling was conducted in each of the main sub-basins of the lake, the Logone and the Chari sub-basins. The dominant contribution of silicate weathering was assessed, and the contribution of each sub-basin was estimated. The estimated total weathering flux was compared to data obtained in the early 1970s and to other neighboring African watersheds.

\section{Study area}

\subsection{Geological and geomorphological context}

The Chari-Logone catchment $\left(61310^{3} \mathrm{~km}^{2}\right)$ is bordered by moderate elevation mountain ranges (285 - 1400m): Adamaoua (South-West), Kaggas (South), Ouaddai (East) and Guera (North), and remains mainly flat elsewhere, with areas seasonally flooded along the river courses (Fig. 1). The main geological features of the Chari and Logone basins show two main units (Louis 1970; Gac 1980). In the South and North-East, the Precambrian basement outcrops, mainly represented by granites (46\%), and different metamorphic rocks (e.g. migmatites, quartzites, gneiss, schists and micaschists). Ferralitic sesquioxide soils are derived from these formations (Pias 1968). The Center and North-Western parts are covered with sedimentary series of the Tertiary (Continental Terminal sandstone formation) and late Quaternary (fluviatile or fluviallacustrine formations). While the sedimentary formations constitute the main aquifer systems (Schneider \& Wolf 1992), groundwater also circulates in hard rocks of the Precambrian basement (Schneider \& Wolf 1992) supporting baseflow in the upper part of the Chari-Logone catchment (Bouchez et al. 2019).

\subsection{Climate and hydrography}

Dominated by the seasonal variation of the intertropical convergence zone (ITCZ), the climate of the Chari-Logone catchment area reflects the confluence between two air masses: the southwestern humid monsoon of oceanic origin and the north-easterly dry Harmattan of continental origin. Thus, depending on the season, from south to north, the Chari-Logone basin shows a gradual transition from humid to semi-arid conditions. The average precipitation rate, calculated from the General Directorate of National Meteorology of Chad (DGMN) dataset, is 
$544 \mathrm{~mm}$ at N'Djamena, between 1984 and 2014. The rainy season starts in May and ends in October and most precipitation falls in July and August (Fig. 2a). The evaporation rates show a well-marked seasonal cycle following the air temperature cycle (Fig.2b).

The basin is drained by two main hydrographic networks, the Logone and the Chari rivers. The Logone river, with a length of $1000 \mathrm{~km}$, originates in the Adamawa plateau in Cameroon, with an altitude ranging from 305 to $835 \mathrm{~m}$ (Cabot 1965; Gac 1980). The Chari Basin covers an area of approximately $52310^{3} \mathrm{~km}^{2}$. The convergence of the Chari and the Logone rivers is located in N'Djamena, $110 \mathrm{~km}$ upstream of Lake Chad, (Fig. 1). The total area of the Logone catchment is $9010^{3} \mathrm{~km}^{2}$ at the confluence with the Chari. The Chari starts in the Central African Republic at an altitude between 500 and $600 \mathrm{~m}$. It flows nearly $1200 \mathrm{~km}$ from the Central African Republic to the Lake Chad. The Chari-Logone receives water input from groundwaters of the Precambrian basement upper basin while in the lower part the Chari-Logone water flows from the river towards the Quaternary Aquifer (Bouchez et al. 2019). The Chari-Logone baseflow discharge is supported by only $12 \%$ of the catchment (Bouchez et al. 2019).

\section{Data acquisition}

\subsection{Sampling}

River waters were sampled every month during two periods, between January 2013 and August 2014, and between July 2015 and November 2016. They were collected at three sites (Fig. 1): (i) the Chari at Chagoua (N'Djamena, $12^{\circ} 05^{\prime} 16^{\prime}{ }^{\prime} \mathrm{N}$ and $15^{\circ} 04^{\prime} 52^{\prime}$ 'E), (ii) the Logone at Nguéli (N'Djamena, 12 $044^{\prime} 08^{\prime \prime} \mathrm{N}$ and $15^{\circ} 03$ '14' 'E), both sites located upstream of the confluence, and (iii) the Chari-Logone at Douguia $\left(12^{\circ} 38^{\prime} 24^{\prime \prime} \mathrm{N}\right.$ and $\left.14^{\circ} 49^{\prime} 37^{\prime \prime} \mathrm{E}\right)$, located $30 \mathrm{~km}$ downstream of the confluence.

The physico-chemical parameters ( $\mathrm{T}, \mathrm{pH}$ and electrical conductivity) were measured in situ (Table 1-3). The waters were first filtered on a $0.45 \mu \mathrm{m}$ nylon membrane and cellulose membrane and stored in pre-cleaned HDPE bottles kept in the dark and in a cold room. Water samples for cation analysis were then acidified with ultra-pure nitric acid. Alkalinity was measured few hours after sampling for all samples by colorimetric titration, and three replicates were performed for each sample, which allowed a reproducibility better than 5\%. In table 1-3 we have the values. 


\subsection{Geochemical analysis}

135 Major dissolved elements and Sr concentration were analyzed at the Institute of Environmental 136 Geosciences (IGE) in Grenoble by ion chromatography, calibrated to measure low

137 concentrations as well as at the European Center for Research and Education in Environmental 138 Geosciences (CEREGE). Strontium isotopes were analyzed with a Neptune + plasma-source 139 multi-collector mass spectrometer (MC ICP-MS) on sixty river samples. A preliminary 140 separation and purification of the strontium was carried out. For each sample, a volume of water 141 corresponding to about $200 \mathrm{ng}$ of $\mathrm{Sr}$ was evaporated. The strontium preparation and separation 142 steps were carried out using the Sr-Spec specific resin on a $200 \mu \mathrm{l}$ column. The fraction was 143 evaporated and then attack with $\mathrm{HNO}_{3}+\mathrm{H}_{2} \mathrm{O}_{2}$ to mineralize any organic residues of the Sr144 Spec resin. Then, for the MC-ICP-MS analysis, dry samples were taken up and dissolved with $145 \mathrm{HNO}_{3} 1 \%$. The internal measurement accuracy of the ${ }^{87} \mathrm{Sr} /{ }^{86} \mathrm{Sr}$ ratio is $\pm 8 \times 10^{-6}(2 \sigma)$. The 146 reproducibility of the ${ }^{87} \mathrm{Sr} /{ }^{86} \mathrm{Sr}$ ratio measurements was tested by repetitive analysis of the 147 international standard NBS $987\left({ }^{87} \mathrm{Sr} /{ }^{86} \mathrm{Sr}\right.$ ratio: $\left.0.710240 \pm 0.00002,2 \sigma, \mathrm{n}=59\right)$. This value is 148 similar to the accepted value of $0.710248 \pm 0.000011$ (Thirlwall 1991). Repeated preparations 149 and measurements of a water sample from Lake Chad labelled TCH2 were also carried out to 150 check long term consistency of the overall $\mathrm{Sr}$ isotope procedure.

\subsection{Hydrological data}

154 Daily river flows were measured by the Water Resource Directorate (DRE) between 2013 and 1552016 at the same locations as the sampling sites: N'Djamena TP on the Chari-Logone, Chagoua on the Chari and Ngueli on the Logone. No data were available for the Logone at Ngueli between 2013 and 2014. The Chari -Logone regime is characterized by a flood period that starts with the rainy season in August and lasts until October when it reaches its maximum (Fig. 2b).

159 The recession starts at the end of October and lasts until December, and low discharges continue

160 from January to June. There is a time lag of two months between the maximum of rainfall and 161 the maximum of discharge measured for the Chari-Logone at N'Djamena (Fig. 2b). The average 162 annual flows in 2013 and 2014 were respectively 804 and $862 \mathrm{~m}^{3} \cdot \mathrm{s}^{-1}$ at the N'Djamena station 163 (i.e. runoff of 41 and $44 \mathrm{~mm} / \mathrm{y}$ respectively). These two years are considered "wet" compared 164 to the inter-annual average of $689 \mathrm{~m}^{3} \cdot \mathrm{s}^{-1}$ (value calculated for the period 1985 to 2015, data 165 source: DRE). 


\subsection{Reconstruction and validation of discharge data}

168 Discharge data are essential to interpret hydro-geochemical behavior, to calculate weighted annual average concentrations, and to estimate chemical fluxes. A linear interpolation was used to fill the gaps in the Chari river discharge time series at the Chagoua station, in order to have a complete daily record for a hydrological year (2013-2014). These gaps occur mainly during

172 low flow periods.

173 For the Logone, in the absence of gauging stations before the confluence of the two rivers, the flow data were reconstructed from a mass balance based on the $\mathrm{Sr}$ isotopic signature:

$$
\left.\left.\left.\frac{{ }^{87} S r}{{ }^{86} S r}\right)_{C L}=\alpha \frac{{ }^{87} S r}{{ }^{86} S r}\right)_{L}+(1-\alpha) \frac{{ }^{87} S r}{{ }^{86} S r}\right)_{C}
$$

where the subscripts CL, C and L point to the Chari-Logone, Chari and Logone respectively. $\alpha$ is the proportion of the Chari-Logone $\mathrm{Sr}$ isotopic signature coming from the Logone river, also corresponding to the $\mathrm{Sr}$ fluxes balance as follows:

$$
\alpha=\frac{[\mathrm{Sr}]_{\mathrm{L}} * \mathrm{Q}_{\mathrm{L}}}{[\mathrm{Sr}]_{\mathrm{CL}} * \mathrm{Q}_{\mathrm{CL}}}
$$

where $\mathrm{Q}$ is the river discharge. This method assumes that chemical fluxes are conservative. The Logone river discharge is then calculated as a function of $\alpha, \mathrm{Q}_{\mathrm{CL}}$, and $\mathrm{Sr}$ concentrations measured in the Logone and in the Chari-Logone river water. This method is also used to calculate an independent Chari discharge value.

\section{Results}

\subsection{Chemical and isotopic compositions}

The conductivity measured on the field is well correlated with the alkalinity. However, the alkalinity obtained from the Chari in April 2013 appeared as an outlier, 20\% above the value expected from the correlation and was ruled out, suspecting a a possible sample pollution after

192 the water collection. The results of ionic and molecular concentrations and strontium isotopic 193 composition of the Chari, Logone and Chari-Logone rivers are shown in Fig. 3 and in Tables

194 1, 2 and 3. Ionic proportions (Fig. 3) show that anion concentrations are largely dominated by $195 \mathrm{HCO}_{3}$, which represents, whatever the station, more than $97 \%$ of the sum of the anions (in meq. $\mathrm{L}^{-1}$ ), the remaining being represented by chloride (about $2.5 \%$ of the anion charge), while 
meq/L) are slightly dominated by $\mathrm{Ca}(34 \%)$, closely followed by $\mathrm{Mg}(29 \%)$, and $\mathrm{Na}(25 \%)$. K represents between 11 and 14\% of the cationic composition. Dissolved silica represents an average of $0.152 \pm 0.014 \mathrm{mmol} / \mathrm{L}$.

201 Strontium data show higher concentrations and lower radiogenic signatures $(0.0012 \pm 0.0003$ $\mathrm{meq} / \mathrm{L}, \mathrm{n}=20 ; 0.7120 \pm 0.0002, \mathrm{n}=20)$ for the Logone, compared to the Chari river $(0.0009 \pm$ $0.0003 \mathrm{meq} / \mathrm{L}, \mathrm{n}=20 ; 0.7170 \pm 0.0005, \mathrm{n}=20)($ Tables 1 to 3$)$. The average for the ChariLogone is $0.0010 \pm 0.0003 \mathrm{meq} / \mathrm{L}(\mathrm{n}=20)$ and $0.7145 \pm 0.0008(\mathrm{n}=20)$.

\subsection{Seasonal variations}

207 Considering its dominance in anion concentration, $\mathrm{HCO}_{3}$ can be considered as a good proxy of 208 the global dissolved load. $\mathrm{HCO}_{3}$ shows a minimum concentration during the rainfall season 209 (July-August) (Fig. 4b). Then it increases until November-December and remains at high levels 210 until the end of the dry season (March-April). Despite a higher average concentration compared 211 to the other cations (Fig. 4c and 4d), Ca undergoes the strongest decrease during the rainfall 212 season. This is particularly evident in the Chari river. In addition, the $\mathrm{Ca} / \mathrm{Na}$ molar ratio shows 213 a sharp drop during the beginning of the rainfall season, and then increases during the flood rise 214 and the flood recession. In both rivers, the $\mathrm{Ca} / \mathrm{Na}$ ratio also displays a small decrease 215 synchronous with the maximum discharge (Fig.4e et a).

216 The strontium content shows the same pattern as other dissolved elements in the Chari and 217 Logone rivers, and most particularly with a behavior similar to that of other alkaline earths 218 elements ( $\mathrm{Ca}$ and $\mathrm{Mg}$ ): the highest values are observed in April and the lowest in July (Fig. 5a). 219 The isotopic signature is rather stable over the period in the Logone and in the Chari. In contrast, 220 the Chari-Logone isotopic signature is highly variable, as a result of the mixing between the 221 two tributaries, with variable contributions along the year (Fig. 5b).

222 The Chari and Logone flow rates calculated using the Sr isotopic mass balance method are 223 shown in Figure 5c. It led to values consistent with the Chari and the Chari-Logone measured 224 river discharge. 


\section{Discussion}

\subsection{Contribution of silicate weathering to the dissolved load}

\subsubsection{Atmospheric contributions}

234 The atmospheric contribution to the dissolved load is classically based on marine elemental 235 ratios, assuming that chloride comes exclusively from atmospheric inputs. Thus, atmospheric contributions are estimated by:

$$
X_{a t m}=C l_{\text {riv }} *\left(\frac{X}{C l}\right)_{\text {sea }}
$$

where $\mathrm{X}$ corresponds to any elemental concentrations, in seawater (sea), river water (riv) and atmospheric inputs $(\mathrm{atm})$.

240 In the Chari and Logone rivers (Table 4), this calculation yields atmospheric Na concentrations between 12 and $14 \mu \mathrm{mol} / \mathrm{L}$ (i.e. $9.1 \%$ of the total Na concentration), and low atmospheric input concentrations of other elements: 1 to $1.7 \mu \mathrm{mol} / \mathrm{L}$ for $\mathrm{Mg}(1.9 \%) ; 0.2$ to $0.3 \mu \mathrm{mol} / \mathrm{L}$ for $\mathrm{K}$ $(0.4 \%)$ and $\mathrm{Ca}(0.3 \%)$. These low atmospheric inputs show that the river geochemistry is dominated by continental weathering. The low atmospheric inputs together with the absence of saline rocks in the basin explain the very low $\mathrm{Cl}$ concentrations measured over the basin and in the Chari Logone (Bouchez et al. 2016).

\subsubsection{A silicate weathering signature}

249 In this section we attempt to elucidate the geological nature and the reservoirs responsible for 250 the chemistry of the Chari-Logone basin.

251 Several studies implemented mixing methods based on the relationships between molar ratios $\left(\mathrm{Ca} / \mathrm{Na}, \mathrm{Mg} / \mathrm{Na}, \mathrm{HCO}_{3} / \mathrm{Na}\right)$ to characterize the different poles (end-members) that can contribute to the dissolved charge of a river, namely the chemical weathering of the different

254 lithological facies (carbonate rocks, silicate rocks and evaporitic rocks) (Négrel et al. 1993;

255 Gaillardet et al. 1999; Picouet et al. 2002). This method relies on the idea that the water 256 chemical composition carries a specific signature attributed to each altering rock, characterized 257 by ionic ratios, which are conservative during evaporation and dilution processes. The river water composition results from the simple combination of these weathering signatures, depending on the lithological facies within a watershed (Négrel et al. 1993, Picouet et al. 2002),

260 after removing the atmospheric contribution. The geochemical signatures of carbonate rocks, 
silicate rocks or evaporitic rocks results from literature databases, and a global synthesis was proposed by Gaillardet et al. (1999).

263 Therefore, the proportion of the geological nature of the rocks presently weathered in the Chari264 Logone catchment can be estimated using the annual average ratios of $\mathrm{Ca} / \mathrm{Na}, \mathrm{Mg} / \mathrm{Na}$ and $265 \mathrm{HCO} 3 / \mathrm{Na}$ of river water, compared to predefined end-members compositions based on the synthesis of Gaillardet et al. (1999). Mixing diagrams of ionic ratios corrected from atmospheric contributions were plotted and compared to worldwide river data (Fig. 6). The mean molar ratios of the Chari, the Logone and the Chari-Logone rivers are very low (e.g. for the ChariLogone: $\mathrm{Ca} / \mathrm{Na}=0.85 \pm 0.19 ; \mathrm{Mg} / \mathrm{Na}=0.63 \pm 0.10 ; \mathrm{HCO}_{3} / \mathrm{Na}=4.2 \pm 0.58$ and close to the composition of the silicate endmember taken from the synthesis of Gaillardet et al (1999): $\mathrm{Ca} / \mathrm{Na}=0.35 \pm 0.15 ; \mathrm{Mg} / \mathrm{Na}=0.24 \pm 0.12 ; \mathrm{HCO}_{3} / \mathrm{Na}=2 \pm 1$, despite a slight shift towards the carbonate endmember (Fig. 6). This could be due to the expected variability of the silicate endmember composition, as Gaillardet et al. (1999) underlined that the natural variations of silicate lithological facies could overcome the range defined by this end-member composition. In addition, although no carbonate formation outcrops in the southern part of the watershed, the presence of pedogenic carbonate nodules in the north of Cameroon has been observed, which formation relies on local sources of Ca coming from in situ weathering (Dietrich et al. 2017). These carbonate nodules are widespread in the Chari-Logone basin, and their dissolution, which could modify the molar ratio without modification of the Sr isotopic signature, may also explain this slight shift towards higher $\mathrm{Ca} / \mathrm{Na}$. Therefore, even if silicate weathering appears as the dominant process controlling the chemistry of the Chari-Logone River, in agreement with the geology, one could not rule out the contribution of secondary carbonate dissolution. This would imply a "local carbon cycle", in which atmospheric carbon consumption associated with the classical mechanism of silicate weathering, would be partly released during the weathering of secondary minerals.

\subsubsection{Comparison with other African systems}

Total dissolved solid (TDS: sum of $\mathrm{SiO}_{2}, \mathrm{Ca}, \mathrm{Mg}, \mathrm{Na}, \mathrm{K}, \mathrm{HCO}_{3}, \mathrm{Cl}$ and $\mathrm{SO}_{4}$ ) represents 55 and $56 \mathrm{mg} / \mathrm{L}$ for the Chari and Logone respectively (Table 5). These values are very low, with the same magnitude as those of the Niger (Table 5), which watershed also corresponds to silicate geological formations. Table 6 shows the mean values in $\mu \mathrm{mol} / \mathrm{L}$ and $\mu \mathrm{eq} / \mathrm{L}$ of all dissolved chemical elements in relation to global and African river values. All these values of African rivers are below the world mean values obtained by Meybeck (2003). 
The $\mathrm{HCO}_{3}$ content of the Chari-Logone system is similar to that of the downstream Niger River, but higher than that of the Congo River and of the upper part of the Niger basin (Table 6).

296 Dissolved silica is important to consider when estimating chemical denudation and $\mathrm{CO}_{2}$ consumption, because its presence in solution is almost entirely due to silicate weathering 298 (Négrel et al. 1993; Gaillardet et al. 1997; Amiotte Suchet et al. 2003; Harmon et al. 2016). It 299 is predominant in the Chari and Logone rivers, with a mean annual value of 159 to $153 \mu \mathrm{mol} / \mathrm{L}$

300 respectively, which is similar to the average world river concentration of silica, but lower than 301 for the Niger river. Except for the K concentration, the annual average levels of the other dissolved elements $(\mathrm{Ca}, \mathrm{Mg}, \mathrm{Na})$ are lower than the overall mean value (Table 6). This low dissolved mineral value can be explained by the morphology of the flattened watershed and the nature of the already leached bedrock.

\subsection{Concentration-discharge relationship at the seasonal scale}

As described previously, there are strong seasonal variations in the concentrations of dissolved chemical elements in the Chari and Logone waters. The lowest concentrations are observed during the rainy season, suggesting a dilution effect by rainfall and rapid runoff, while the highest values are observed during the dry season, when the influence of evaporation is strong. When chemical concentrations are compared with river discharge, the relation shows a hysteresis loop, suggesting a non-linear behavior of the catchment (Fig. 7). This hysteresis

313 behavior is well observed for $\mathrm{Ca}$ and $\mathrm{Mg}$ in the Chari and Logone rivers, and for $\mathrm{Na}$ in the

314 Logone River while K shows constant concentrations throughout the year, except during the 315 months of lowest discharge in April and May. Hysteresis behaviors between chemical elements 316 and river flows are observed in several basins around the world (Walling and Foster 1975;

317 Walling and Webb 1980; Probst et al. 1992; Evans and Davies 1998; Bravard and Petit 2000; 318 Picouet et al. 2002; Calmels et al. 2011; Moquet et al. 2016; Bouchez et al. 2017; Ibarra et al. 319 2017). Some explanations involve the contribution of different reservoirs. For example, in the 320 Niger Basin (Picouet et al. 2002) the hysteresis behavior was interpreted as: (1) a variable 321 seasonal contribution of different flow sources (runoff, hypodermic flow, groundwater), (2) a 322 delayed contribution of the various branches of the hydrographic network and (3) a flushing effect of the ponds with the new flood, which brings water that has been concentrated during the dry season. In addition, this flushing effect can also lead to the mobilization of soluble minerals deposited in the minor bed during the dry season, and on leaching of soil horizons. 
326 For the Chari and Logone basins, the seasonal variations of the $\mathrm{Ca} / \mathrm{Na}$ ratio indicate that different water sources are involved, in addition to the combined effects of dilution by rainfall and of concentration by evaporation. Nevertheless, the relationship between $\mathrm{Ca} / \mathrm{Na}$ and discharge is more complex than a simple hysteresis loop: the discharge rising months $\mathrm{p}$ are characterized by an increase of $\mathrm{Ca} / \mathrm{Na}$, followed by a slight decrease at the flood maximum, and thereafter, the $\mathrm{Ca} / \mathrm{Na}$ ratio remains constant during the flood recession, leading to a "double loop" (Fig. 7).

333 The highest constant $\mathrm{Ca} / \mathrm{Na}$ ratios are observed during the low flow period (January-March), when river flow is supported by groundwater, while the lowest ratios are observed during the rainfall season, when rapid runoff dominates the water flow. Therefore, the variations of $\mathrm{Ca} / \mathrm{Na}$ could result from the different residence time of water in the catchment.

As discussed above, the $\mathrm{Ca} / \mathrm{Na}$ ratio reflects the geological nature of weathed formations. During the rainfall season, $\mathrm{Ca} / \mathrm{Na}$ reaches a low value similar to that of the silicate end-member defined by Gaillardet et al. 1999 (Fig. 4-d). The increase of $\mathrm{Ca} / \mathrm{Na}$ above this value may result from to the contribution of pedogenic carbonates weathering, thus more intense for longer residence time.

342 Then, the two-fold peak of $\mathrm{Ca} / \mathrm{Na}$ could be attributed to the dual effect of 1) leaching and mobilisation of water that remained stored in the catchment, during the flood formation; and 2)

344 groundwater signature, during the flood recession and low flow period. In between these two peaks, during the maximum discharge, the $\mathrm{Ca} / \mathrm{Na}$ ratio displays intermediate values, resulting from the mixing between the two water sources.

347 The influence of groundwater signature during the flood recession in November-December, 348 when the baseflow dominates river discharge, is also visible through stable elemental concentrations. From January until the beginning of the rainfall season, concentrations increase under the influence of evaporation. Then, when the rainfall season begins (April in the upper catchment), the persistent effect of evaporation compensates the dilution by rainfall. This explains that the $\mathrm{Ca} / \mathrm{Na}$ ratio decreases together with the elemental concentrations, while the discharge remains low. The concentration of dissolved chemicals continue to decrease until July-August, consistently with the increase in discharge. This corresponds to the dilution of the river water by less concentrated water coming from precipitation. Discharge continues to increase until October while concentrations also increase. This can be attributed to the increasing contribution of more concentrated groundwaters, but also to the remobilization of chemical elements by the effect of land leaching by rains in the floodplains of Massenya for the

359 Chari, and of Bongor and Yaeré for the Logone (Fig. 1). 
This anti-clockwise hysteresis behavior well pronounced for $\mathrm{Ca}$ and $\mathrm{Mg}$ and less for $\mathrm{Na}$ and $\mathrm{K}$ is thus mainly driven by the contribution of two main water sources, rapid surface and subsurface water flow on one hand, and groundwater on other hand, i.e. "pre-event water", which carry a higher $\mathrm{Ca} / \mathrm{Na}$ signature.

364

\subsection{Driving factors of silicate weathering fluxes}

\subsubsection{Annual average weathering fluxes in Chari and Logone sub-basins}

The annual weighted average concentrations for 2013 were multiplied by the annual river discharge to calculate the annual total flux expressed in ton/y and specific flux $\left(\mathrm{g} / \mathrm{m}^{2} / \mathrm{y}\right)$ (Table 7). For the entire Chari-Logone basin, the TDS flux was estimated at $2.21 \mathrm{~g} / \mathrm{m}^{2} / \mathrm{y}$. Despite its higher contribution, i.e. $1.38^{*} 10^{6} \mathrm{t} / \mathrm{y}$, while the Logone provides $0.58^{*} 10^{6} \mathrm{t} / \mathrm{y}$, the Chari river has a lower TDS specific flux, i.e. $1.59 \mathrm{~g} / \mathrm{m}^{2} / \mathrm{y}$, compared to $6.16 \mathrm{~g} / \mathrm{m}^{2} / \mathrm{y}$ for the Logone. Our data similar geochemical concentrations between the two rivers. Therefore, the observed difference in specific weathering flux is mainly due to runoff differences between the Chari (29 $\mathrm{mm} / \mathrm{y})$ and Logone $(112 \mathrm{~mm} / \mathrm{y})$ river basins. This situation corresponds to transport-limited weathering regimes, also refered to as chemostatic behaviors, in which the runoff rate is the only factor controlling chemical fluxes (Godsey et al. 2009 and Koger et al. 2018).

\subsubsection{Comparison with historical data on the Chari-Logone}

To elucidate the question of the direct link between chemical and water fluxes, i.e. chemostatic behavior, it is interesting to compare our data with different magnitudes of runoff conditions, such as those that occurred during previous periods during the last 50 years. Dissolved loads and chemical fluxes were compared to data obtained in 1969, 1972 and 1973 (Gac 1980 and from Bouchez et al. 2016). The corresponding average annual flows (measured at station of N'Djamena on the Chari-Logone) were $1076 \mathrm{~m}^{3} \mathrm{~s}^{-1}, 577 \mathrm{~m}^{3} \mathrm{~s}^{-1}$ and $576 \mathrm{~m}^{3} \mathrm{~s}^{-1}$ in 1969,1972 and 1973 respectively (Carmouze, 1976, Gac, 1980, Roche, 1980, Olivry et al., 1996). The year 1969 is the wettest of our data set and corresponds to the beginning of the so-called "Great Sahelian drought" of the 1970-1980 period. Fig. 8 presents a comparative study of dissolved loads between these pre-drought period and present day conditions. The sum of the cations $(\mathrm{Ca}$ $+\mathrm{Mg}+\mathrm{Na}+\mathrm{K}$ ) varied in the range 8.7 to $14.4 \mathrm{mg} / \mathrm{L}$ in 1969 (Gac 1980; Roche 1980); 8.7 to $14.6 \mathrm{mg} / \mathrm{L}$ in 1972 (Carmouze 1976, Gac 1980) and 8.7 to $19.9 \mathrm{mg} / \mathrm{L}$ in 2013 (this study). The most variable concentrations are those encountered during the dry season (March-June), which 
showed higher values in recent years, while the flood season (September-November) displayed surprisingly constant values, independently of the discharge magnitude (Fig. 8). The annual chemical flux is dominated by the flood season: even with higher concentrations during the low water period, the March-June period only contributes to $11 \%$ of the annual flux. Thus, the concentration variations observed during low flow periods have little effect on the annual flux.

396 The comparison between historical and recent data shows that for the Chari-Logone system,

397 the inter-annual variability of high flow concentrations is very low, even during the more humid 398 years prior to the 1970s Sahelian drought. As the flood period dominates the total annual export, 399 it can thus be concluded that the annual weathering load exported is directly related to the 400 runoff.

\subsubsection{Impact of semi-arid environments on the carbon cycle}

403

404

405

406

407

408

409

410

411

412

413

414

415

416

417

418

419

420

421

422

In the strongly contrasted climatic context of the Chari basin, the very low average runoff (29 $\mathrm{mm} / \mathrm{y}$ in 2013) is due to the fact that some sub-basins do not contribute to the runoff, especially in the Sahelian part of the catchment. Indeed, the chloride mass balance of the Chari-Logone basin showed that only $12 \pm 8 \%$ of the catchment is connected to the main rivers (Bouchez et al. 2019). In many parts of the basin, evaporation encompasses all other fluxes, leading to endorheic situations where dissolved load is not exported to the outflow. These disconnected areas become productive during more humid periods, leading to a significant increase in chemical fluxes. In addition, the precipitation of secondary minerals, such as pedogenic carbonate nodules, may be enhanced in these endorheic areas.

Therefore, the impact of semi-arid areas on the carbon cycle are two-fold. First, there is a direct positive relationship between hydrological fluxes and atmospheric carbon consumption by silicate weathering. As the hydrological response to climate change is particularly amplified in semi-arid environments, the carbon flux response to climate may also be enhanced. Second, the hydrological closure, either local or at the catchment scale, implies that atmospheric carbon consumed by silicate weathering is stored inside the catchment, either in soils (e.g. pedogenic carbonates), either in lakes (e.g. secondary minerals produced by reverse weathering). Although evident, this assertion may have important global implication, since endorheic areas represent an important part of continental surfaces. 


\section{Conclusions}

424 The Chari and Logone basins cover an area of approximately $613000 \mathrm{~km}^{2}$ and drain water from 425 the northern flank of Adamaoua (Cameroon) and the Central African ridge, towards Lake Chad. 426 The analysis of the distribution of the major elements showed that the Chari and Logone rivers

427 are very poorly mineralized and that the dissolved load mainly comes from the weathering of 428 silicates, although the $\mathrm{Ca} / \mathrm{Na}$ ratio may reflect the influence of pedogenic carbonate dissolution.

429 The isotope compositions of strontium confirm the absence of a significant primary carbonate 430 pole on the basin. Substantial seasonal variations of river concentrations are observed, with 431 higher concentrations during the dry season and lower concentrations during the rainy season, 432 but with a delay of about 2 months between the rainfall peak and the flood peak. In the Chari433 Logone basin, we observed that concentrations follow an annual hysteresis, related to a variable 434 contribution over time of surface water and groundwater.

435 Based on the ${ }^{87} \mathrm{Sr} /{ }^{86} \mathrm{Sr}$ ratios, we estimated that the Chari and the Logone rivers respectively 436 contributed to $59 \%$ and $41 \%$ of the total dissolved load to Lake Chad. Silicate weathering 437 largely dominated the dissolved load. A flux of $5.9 * 10^{5}$ tons/y of dissolved materials 438 transported to Lake Chad was estimated downstream of N'Djamena for the year 2013. The 439 Chari Logone Basin follows a chemostatic behavior. Therefore, the inter-annual variations of 440 dissolved loads reaching Lake Chad are directly related to the variations in the Chari-Logone 441 discharge.

\section{Acknowledgments}

444 This work was supported by the French National Research Institute for Sustainable 445 Development (IRD) in the framework of the project 'Préservation du Lac Tchad: Contribution 446 à la stratégie de développement du lac' funded by 'Fond Français de l'Environnement Mondial' 447 and by 'Agence Française pour le Développement'. The authors are grateful to the University 448 of N'Djamena, the Centre National de la Recherche pour le Développement of Chad (CNRD) 449 and the French Embassy in Chad for their logistical support. We thank Hélène Mariot for the 450 preparation of the chemistry and the analysis of the major elements and Abel Guihou for the 451 analysis of the isotopic composition of strontium. 


\section{References}

Agbri L, Bamba S, Doumouya I, Savane I (2010) Bilan des flux de matières particulaires et dissoutes du Sassandra à Gaoulou pont (Côte d'Ivoire). Sci Nat 7:107-118. doi:10.4314/scinat.v7i2.59944

Amiotte Suchet P, Probst J-L, Ludwig W (2003) Worldwide distribution of continental rock lithology: Implications for the atmospheric/soil CO2 uptake by continental weathering and alkalinity river transport to the oceans. Glob Biogeochem Cycles 17. doi:10.1029/2002GB001891

Béné, C., Neiland, A., Jolley, T., Ovie, S., Sule, O., Ladu, B., Mindjimba, K., et al. (2003) Inland fisheries, poverty, and rural livelihoods in the Lake Chad Basin. J. Asian Afr. Stud. 38(1), 17-51. doi:https://doi.org/10.1177/002190960303800102

Bouchez C, Goncalves J, Deschamps P, et al (2016) Hydrological, chemical, and isotopic budgets of Lake Chad: a quantitative assessment of evaporation, transpiration and infiltration fluxes. Hydrol Earth Syst Sci 20:1599-1619. doi: 10.5194/hess-20-15992016.

Bouchez J, Moquet J-S, Espinoza JC, et al (2017) River mixing in the Amazon as a driver of concentration-discharge relationships. Water Resour Res 53:8660-8685. doi:10.1002/2017WR020591

Bouchez C, Deschamps P, Goncalves J, et al (2019) Water transit time and active recharge in the Sahel inferred by bomb-produced $36 \mathrm{Cl}$. Scientific Reports 9:7465. doi:10.1038/s41598-019-43514-x

Bravard J-P, Petit F (2000) Les cours d'eau: dynamique du système fluvial. https://www.persee.fr/doc/ingeo_0020-0093_1998_num_62_2_2583_t1_0093_0000_1

Cabot J (1965) Le bassin du moyen Logone. Document de ORSTOM, P.355, Paris. https://www.persee.fr/doc/ingeo_0020-0093_1965_num_29_5_5777

Calmels D, Galy A, Hovius N, et al (2011) Contribution of deep groundwater to the weathering budget in a rapidly eroding mountain belt, Taiwan. Earth Planet Sci Lett 303:48-58. doi: $10.1016 /$ j.epsl.2010.12.032

Carmouze J-P (1976) La régulation hydrogéochimique du lac Tchad: Contribution à l'analyse biogéodynamique d'un système lacustre endoréique en milieu continental cristallin. doc. ORSTOM, Paris, p.413. http://horizon.documentation.ird.fr/exldoc/pleins_textes/pleins_textes_6/Tra_d_cm/08443.pdf

Chorover J, Derry LA, McDowell WH (2017) Concentration-Discharge Relations in the Critical Zone: Implications for Resolving Critical Zone Structure, Function, and Evolution. Water Resour Res 53:8654-8659. doi.org/10.1002/2017WR021111

Dietrich F, Diaz N, Deschamps P, et al (2017) Origin of calcium in pedogenic carbonate nodules from silicate watersheds in the Far North Region of Cameroon: Respective contribution of in situ weathering source and dust input. Chem Geol 460:54-69. doi.org/10.1016/j.chemgeo.2017.04.015

Drever JI, Zobrist J (1992) Chemical weathering of silicate rocks as a function of elevation in the southern Swiss Alps. Geochim Cosmochim Acta 56:3209-3216. doi: 10.1016/00167037(92)90298-W

Evans C, Davies TD (1998) Causes of concentration/discharge hysteresis and its potential as a tool for analysis of episode hydrochemistry. Water Resour Res 34:129-137. doi: 10.1029/97WR01881

Gac J-Y (1980) Géochimie du bassin du lac Tchad: Bilan de l'altération de l'érosion et de la sédimentation, doc. ORSTOM, P.252. http://www.documentation.ird.fr/hor/fdi:00039 
Gaillardet J, Dupre B, Allegre CJ, Négrel P (1997) Chemical and physical denudation in the Amazon River Basin. Chem Geol 142:141-173. https://doi.org/10.1016/S00092541(97)00074-0

Gaillardet J, Dupré B, Louvat P, Allegre CJ (1999) Global silicate weathering and CO2 consumption rates deduced from the chemistry of large rivers. Chem Geol 159:3-30. doi.org/10.1016/S0009-2541(99)00031-5

Godsey SE, Kirchner JW, Clow DW (2009) Concentration-discharge relationships reflect chemostatic characteristics of US catchments. Hydrological Processes: An International Journal 23:1844-1864. DOI: 10.1002/hyp.7315

Harmon RS, Wörner G, Goldsmith ST, et al (2016) Linking silicate weathering to riverine geochemistry-A case study from a mountainous tropical setting in west-central Panama. Bulletin 128:1780-1812. doi:10.1130/B31388.1

Hartmann J, Jansen N, Dürr HH, et al (2009) Global CO2-consumption by chemical weathering: What is the contribution of highly active weathering regions? Glob Planet Change 69:185-194. doi:10.1016/j.gloplacha.2009.07.007

Ibarra DE, Moon S, Caves JK, et al (2017) Concentration-discharge patterns of weathering products from global rivers. Acta Geochim 36:405-409. doi: 10.1007/s11631-0170177-z

Koger JM, Newman BD, Goering TJ (2018) Chemostatic behaviour of major ions and contaminants in a semiarid spring and stream system near Los Alamos, NM, USA. Hydrol Process 32:1709-1716. DOI: 0.1002/hyp.11624

Louis $\mathrm{P}$ (1970) Contribution géophysique à la connaissance géologique du bassin du lac Tchad. ORSTOM, Paris. http://www.documentation.ird.fr/hor/fdi:04616

Louvat P, Allègre CJ (1997) Present denudation rates on the island of Reunion determined by river geochemistry: basalt weathering and mass budget between chemical and mechanical erosions. Geochim Cosmochim Acta 61:3645-3669. doi.org/10.1016/S0016-7037(97)00180-4

Meybeck M (2003) Global occurrence of major elements in rivers. Treatise Geochem 5:207223. doi:10.1016/B0-08-043751-6/05164-1

Meybeck, M. (1987) Global chemical weathering of surficial rocks estimated from river dissolved loads. Am. J. Sci. 287(5), 401-428. doi:10.2475/ajs.287.5.401

Milliman JD, Meade RH (1983) World-wide delivery of river sediment to the oceans. J Geol 91:1-21. doi:10.1086/628741

Moquet J-S, Crave A, Viers J, et al (2011) Chemical weathering and atmospheric/soil CO2 uptake in the Andean and Foreland Amazon basins. Chem Geol 287:1-26. https://doi.org/10.1016/j.chemgeo.2011.01.005

Moquet J-S, Guyot J-L, Crave A, et al (2016) Amazon River dissolved load: temporal dynamics and annual budget from the Andes to the ocean. Environ Sci Pollut Res 23:11405-11429. DOI: $10.1007 / \mathrm{s} 11356-015-5503-6$

Musolff A, Schmidt C, Selle B, Fleckenstein JH (2015) Catchment controls on solute export. Adv Water Resour 86:133-146. DOI: 10.1016/j.advwatres.2015.09.026

Négrel P, Allègre CJ, Dupré B, Lewin E (1993) Erosion sources determined by inversion of major and trace element ratios and strontium isotopic ratios in river water: The Congo Basin case. Earth Planet Sci Lett 120:59-76. doi: 10.1016/0012-821X(93)90023-3

Olivry J-C, Diallo lam M, Bricquet J-P (1994) Quelques données préliminaires sur l'environnement et la qualité des apports du Niger au Sahel. https://www.researchgate.net/publication/32972541_Premiers_resultats_sur_la_me sur 

e_des_flux_de_matieres_dissoutes_et_particulaires_dans_les_apports_du_Niger_au _Sahel

Ollivier P, Hamelin B, Radakovitch O (2010) Seasonal variations of physical and chemical erosion: A three-year survey of the Rhone River (France). Geochim Cosmochim Acta 74:907-927. DOI: 10.1016/j.gca.2009.10.037

Pias J (1968) Contribution à l'étude des formations sédimentaires tertiaires et quaternaires de la cuvette tchadienne et des sols qui en dérivent (République du Tchad). PhD Thesis, Orstom. $\quad$ Retrieved from http://horizon.documentation.ird.fr/exldoc/pleins_textes/cahiers/PTP/18537.PDF

Picouet C, Dupré B, Orange D, Valladon M (2002) Major and trace element geochemistry in the upper Niger river (Mali): physical and chemical weathering rates and $\mathrm{CO} 2$ consumption. Chem Geol 185:93-124. DOI: 10.1016/S0009-2541(01)00398-9

Probst J-L, NKounkou R-R, Krempp G, et al (1992) Dissolved major elements exported by the Congo and the Ubangi rivers during the period 1987-1989. J Hydrol 135:237-257. doi.org/10.1016/0022-1694(92)90090-I

Roche M-A (1980) Traçage naturel salin et isotopique des eaux du système hydrologique du lac Tchad. ORSTOM, Paris, p.391/ Retrieved fromhttp://www.documentation.ird.fr/hor/fdi:00328

Schneider J-L, Wolf JP (1992) Carte géologique et hydrogéologique de 1/500 000 de la republique du Tchad, mémoire explicatif. BRGM, p.531, Paris

Schuster, M., Roquin, C., Duringer, P., Brunet, M., Caugy, M., Fontugne, M., Mackaye, H. T., et al. (2005) Holocene lake Mega-Chad palaeoshorelines from space. Quat. Sci. Rev. 24(16-17), 1821-1827. DOI: 10.1016/j.quascirev.2005.02.001

Sylvestre F., (2014) Variabilité paléohydrologique et changements climatiques, In Lemoalle J., Magrin G. (dir.) : Le développement du lac Tchad: situation actuelle et futurs possibles, Marseille, IRD Editions, coll. Expertise collégiale : 79-92.

Thirlwall MF (1991) Long-term reproducibility of multicollector $\mathrm{Sr}$ and $\mathrm{Nd}$ isotope ratio analysis. Chem Geol Isot Geosci Sect 94:85-104. doi:10.1016/0168-9622(91)90002-E

Tipper ET, Bickle MJ, Galy A, et al (2006) The short term climatic sensitivity of carbonate and silicate weathering fluxes: insight from seasonal variations in river chemistry. Geochim Cosmochim Acta 70:2737-2754. doi.org/10.1016/j.gca.2006.03.005

Viers J, Dupré B, Braun J-J, et al (2000) Major and trace element abundances, and strontium isotopes in the Nyong basin rivers (Cameroon): constraints on chemical weathering processes and elements transport mechanisms in humid tropical environments. Chem Geol 169:211-241. doi.org/10.1016/S0009-2541(00)00298-9

Walling DE, Foster IDL (1975) Variations in the natural chemical concentration of river water during flood flows, and the lag effect: some further comments. J Hydrol 26:237-244. https://doi.org/10.1016/0022-1694(75)90005-0

Walling DE, Webb BW (1980) The spatial dimension in the interpretation of stream solute behaviour. J Hydrol 47:129-149. doi.org/10.1016/0022-1694(80)90052-9 


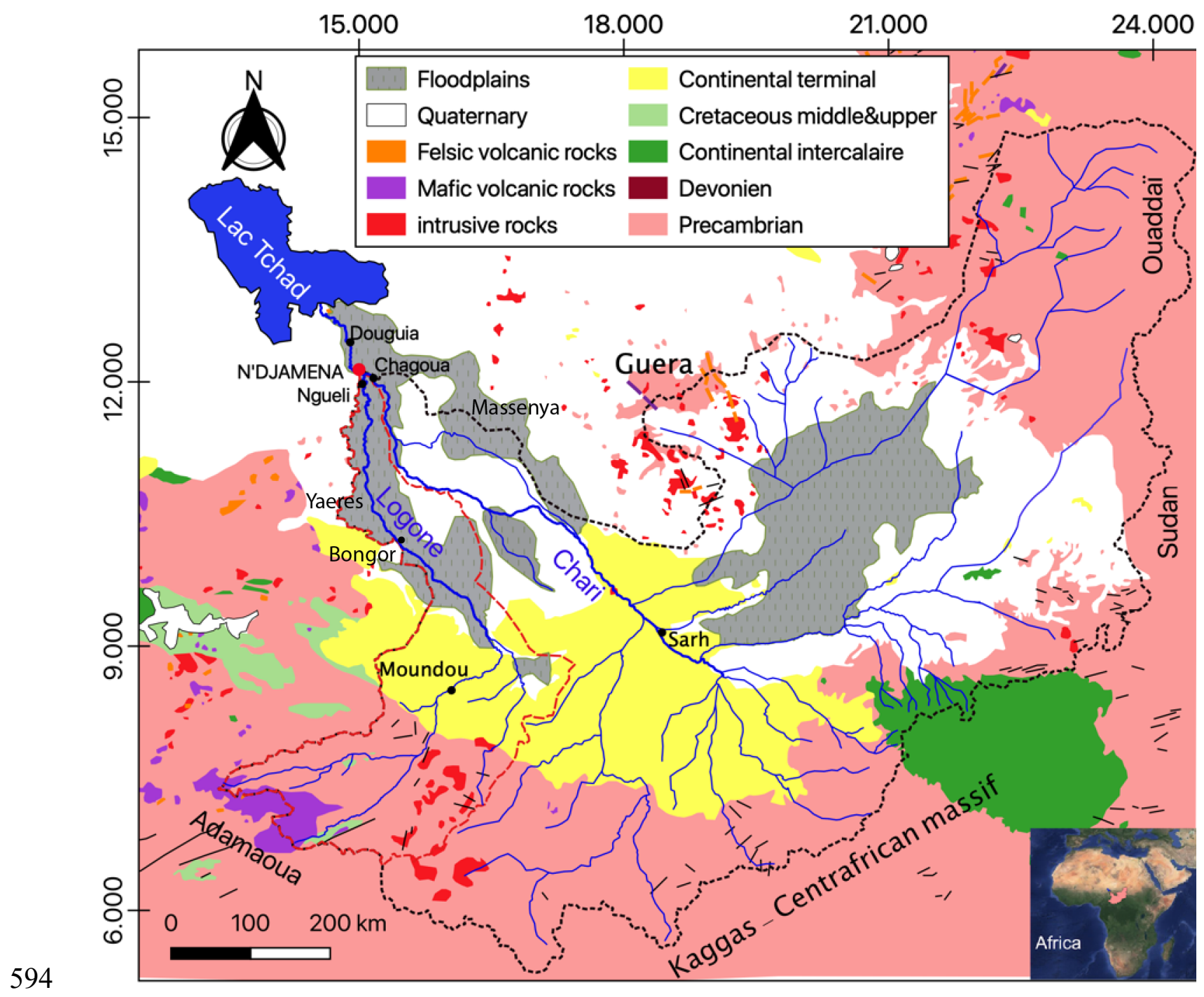

595 Figure 1. Geological map of the Chari-Logone basin (Louis 1970), with sample locations

596 (Ngueli, Chagoua and Douguia). The black dotted line represents the boundary of the Chari-

597 Logone basin and the red dotted line the boundary of the Logone basin. 

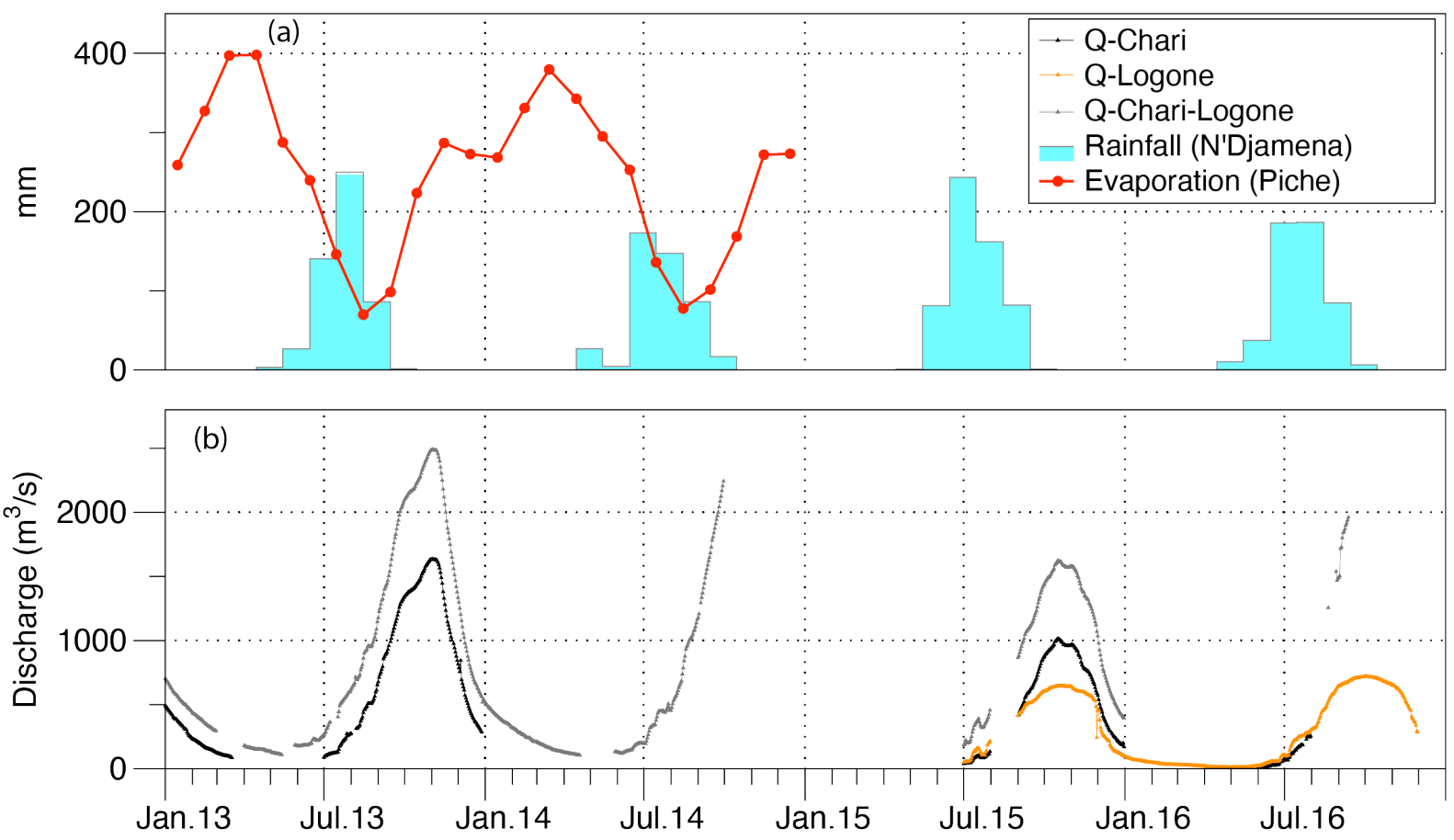

Figure 2: Monthly rainfall and evaporation (Piche method) at the N'Djamena station (a); daily 602 discharge (b): the black dotted curve represents the flow of the Chari river at Chagoua before 603 the confluence, the yellow curve represents the flow of Logone river at Ngueli and the grey 604 curve is the flow of Chari - Logone river after the confluence of the two rivers Chari and Logone 605 measured at N'Djamena.

606 


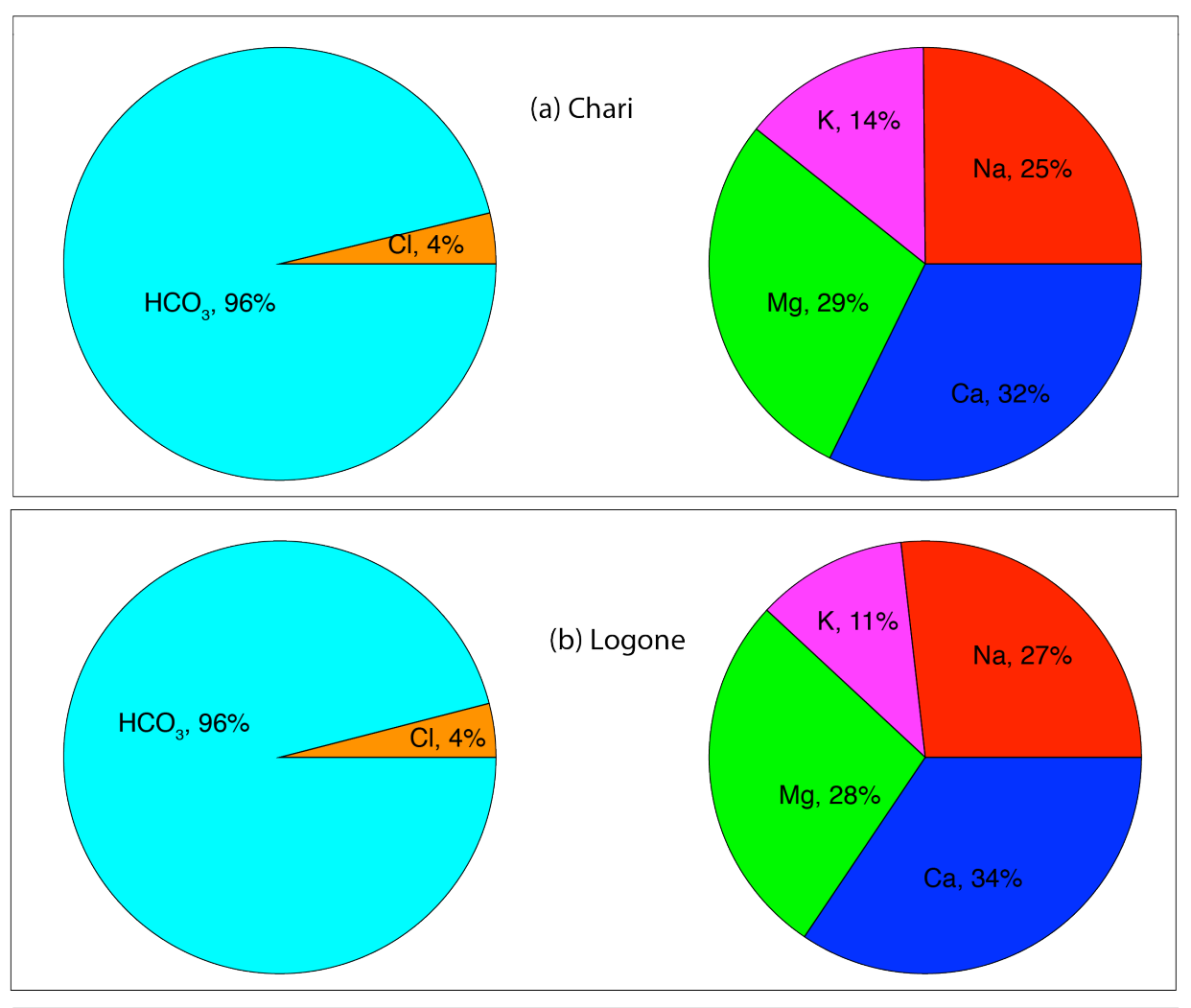

608 Figure 3. Ionic compositions (average annual proportion of each anion and cation in meq/L) 609 of the Logone, Chari and Chari-Logone waters.

610

611

612

613

614

615

616

617

618

619

620 
621
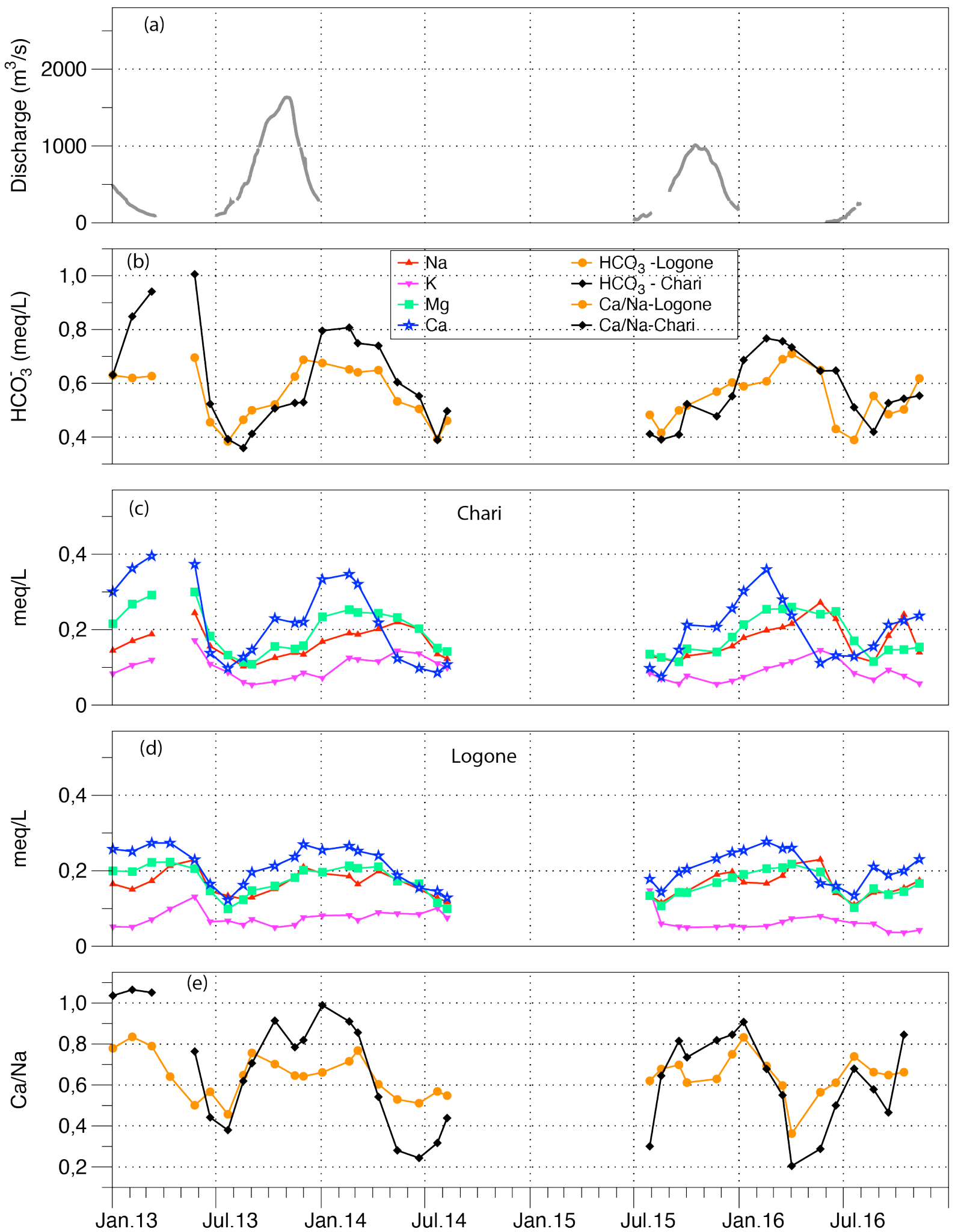

623 Figure 4 : Seasonnal evolution of ionic concentrations and $\mathrm{Ca} / \mathrm{Na}$ molar ratio in the Chari and 624 Logone rivers between 2013 and 2016. The Chari-Logone discharge provides the seasonal flood 625 framework. 

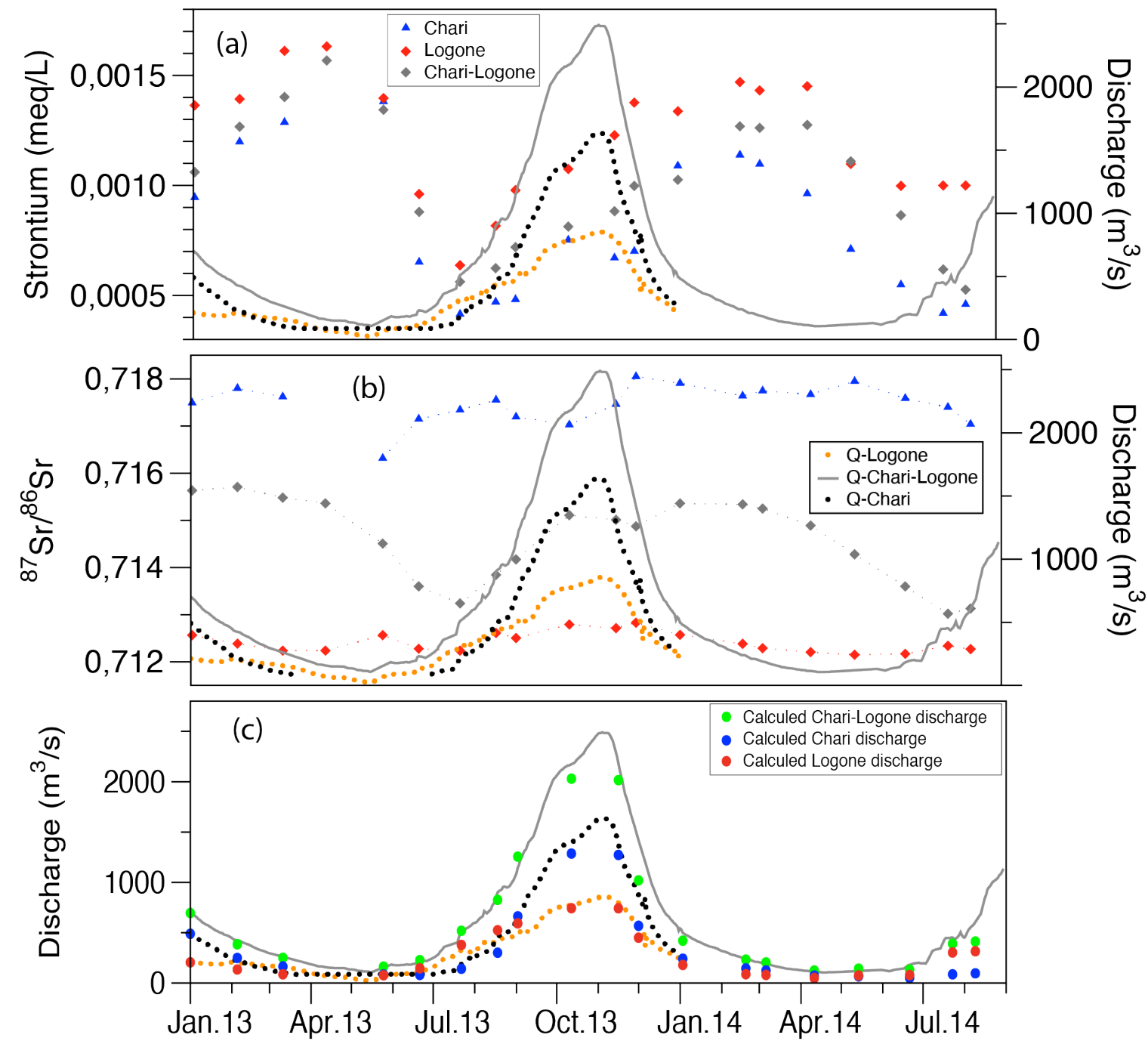

630 Figure 5: Concentration (a) and isotopic composition (b) of strontium in the Chari (blue),

631 Logone (red) and Chari - Logone (grey) water. As in Fig. 2, the grey curve and the black dotted 632 curve are the measured Chari-Logone and Chari river discharges, respectively. The grey dotted 633 curve is the Logone discharge deduced from the difference between the Chari - Logone and 634 Chari data. The colored circles are the flows rates calculated from the strontium isotope ratios 635 mass balance for the Logone (red), Chari (blue), and sum of both values (green). 

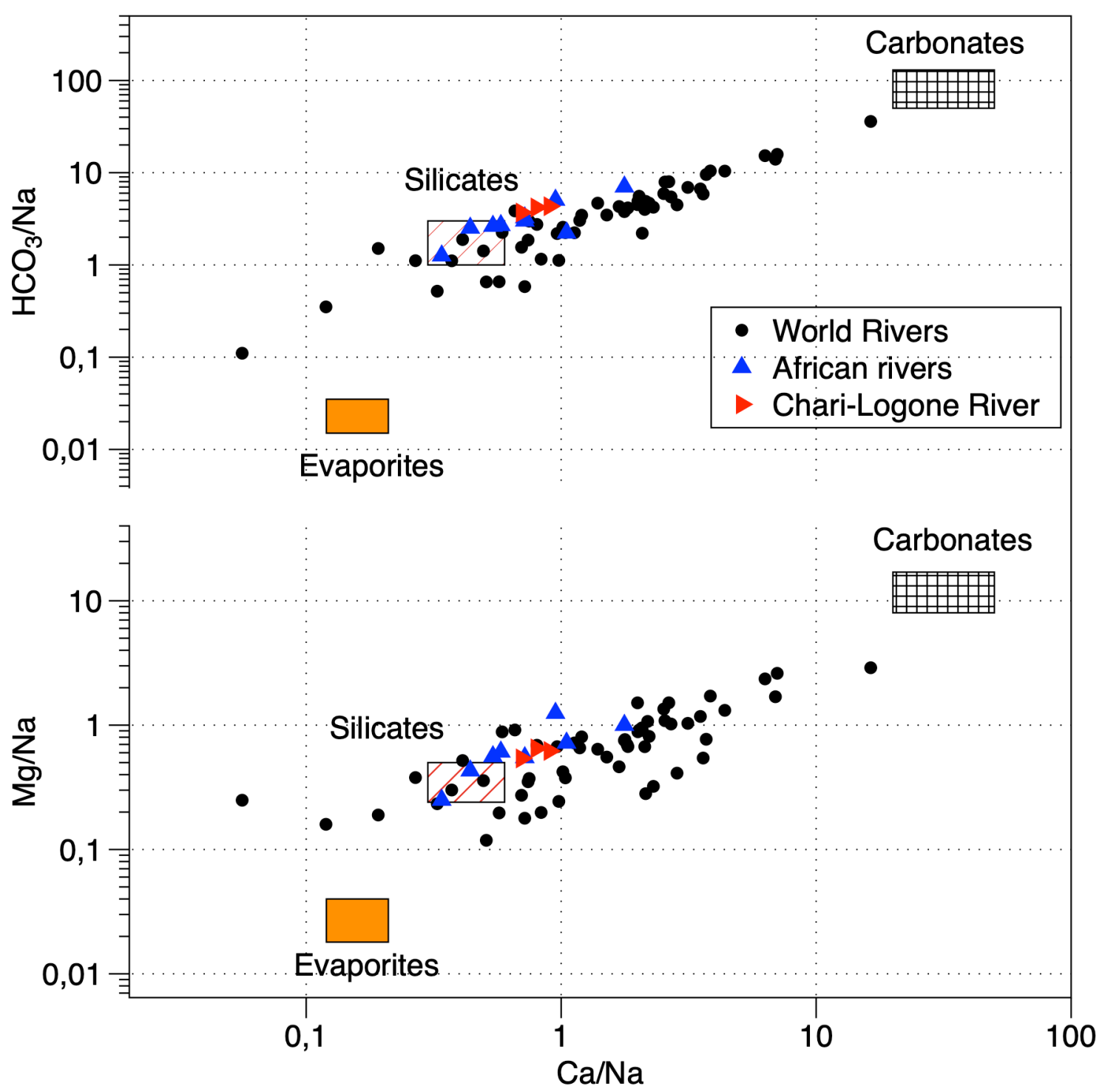

642

$\mathrm{Ca} / \mathrm{Na}$

643 Figure 6: Mixing diagram showing concentration ratios in river water, and in weathering end644 members defined in previous studies. The values of the $\mathrm{Ca} / \mathrm{Na}, \mathrm{Mg} / \mathrm{Na}$ and $\mathrm{HCO}_{3} / \mathrm{Na}$ ratios of 645 the silicate, carbonate, and evaporitic end-members are taken from Gaillardet et al. (1999). The 646 data of the various world and African rivers plotted in this diagram are taken from Gaillardet et 647 al. (1997), Meybeck (2003), Picouet et al. (2002), Orange (1996) and Agbri et al. (2010). 
(a)
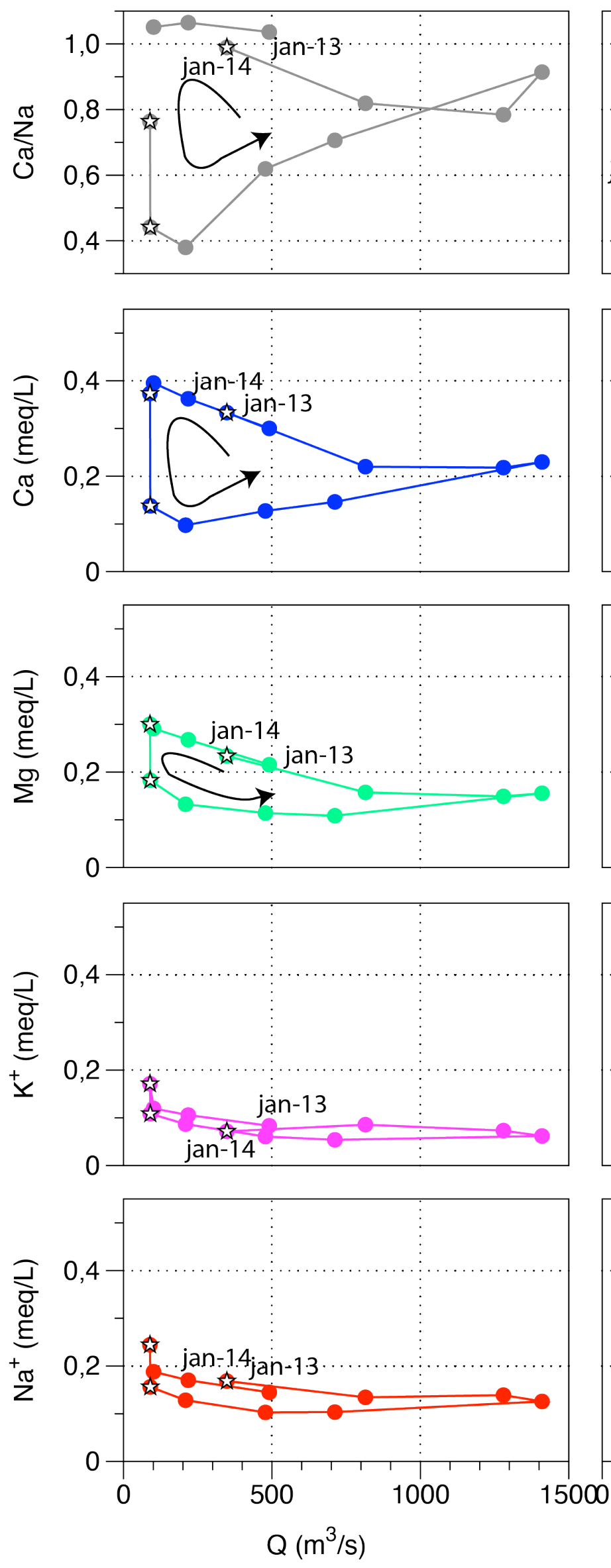

(b)
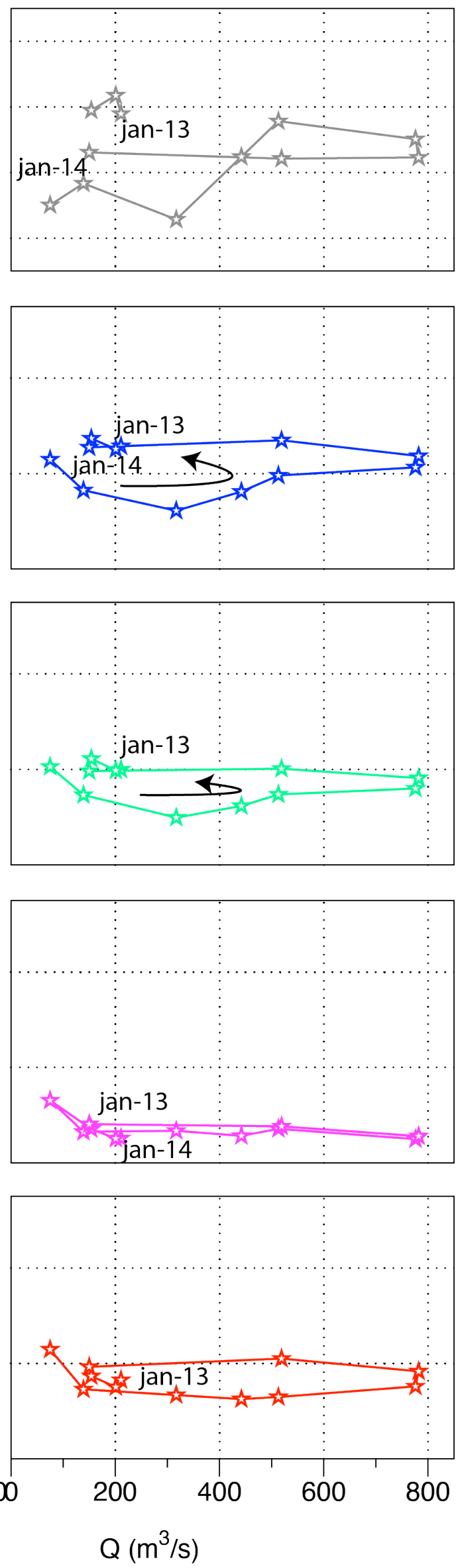
654 Figure 7: Evolution of ionic concentrations $(\mathrm{Ca}, \mathrm{Mg}, \mathrm{K}$ and $\mathrm{Na})$ as a function of the discharge 655 flow of the Chari (a) and the Logone (b) rivers over the 2013-2014 period. Stars correspond to 656 reconstituted flows.

657

658

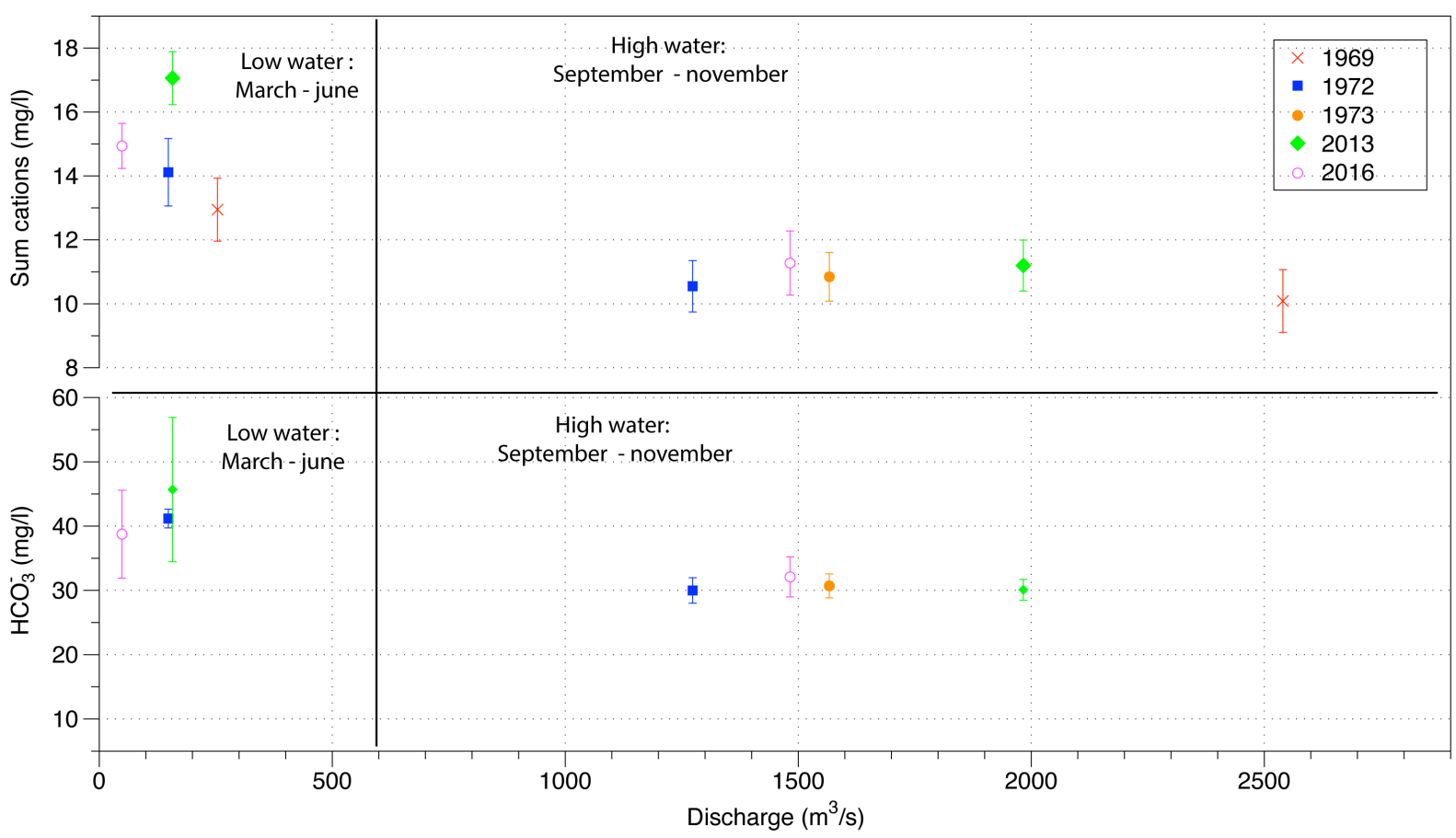

659

660 Figure 8: Average concentrations of the Chari-Logone river corresponding to the two main

661 periods of an annual cycle: low water period (March-June) and high water (flood) period 662 (September-November), compared to 1969, 1972 and 1973 data (from Gac 1980).

663

664

665

666

667

668

669

670

671

672

673 
Table 1: Measured concentrations in Chari River monthly water samples

\begin{tabular}{|c|c|c|c|c|c|c|c|c|c|c|c|c|c|c|c|c|}
\hline \multirow{2}{*}{ Dates } & Q -mesured & Q -calculated & EC & $\mathrm{pH}$ & $T$ & ${ }^{87} \mathrm{Sr} r^{\beta 6} \mathrm{Sr}$ & $\mathrm{SiO}_{2}$ & $\mathrm{Na}^{+}$ & $\mathrm{K}^{+}$ & $\mathrm{Mg}^{2+}$ & $\mathrm{Ca}^{2+}$ & $\mathrm{Sr}^{2+}$ & $\mathrm{Cl}^{-}$ & $\mathrm{SO}_{4}{ }^{2-}$ & $\mathrm{HCO}_{3}^{-}$ & Ionic B. \\
\hline & $\left(\mathrm{m}^{3} / \mathrm{s}\right)$ & $\left(\mathrm{m}^{3} / \mathrm{s}\right)$ & $\mu \mathrm{s} / \mathrm{cm}$ & & ${ }^{\circ} \mathrm{C}$ & \multicolumn{11}{|c|}{$\mathrm{mmol} / \mathrm{L}\left(\mathrm{SiO}_{2}\right)$ and $\mu \mathrm{eq} / \mathrm{L}$ (other elements) } \\
\hline $02 / 01 / 2013$ & 365 & 490 & 74 & 8,3 & 22,0 & 0,7175 & 155 & 145 & 83 & 215 & 300 & 0,9 & 11 & 2 & 631 & 8,2 \\
\hline $05 / 02 / 2013$ & 177 & 250 & 89 & 7,9 & 24,0 & 0,7178 & 136 & 170 & 106 & 268 & 362 & 1,2 & 17 & 1 & 849 & 3,3 \\
\hline $11 / 03 / 2013$ & 104 & 165 & 98 & 8,3 & 26,8 & 0,7176 & 142 & 188 & 120 & 291 & 395 & 1,3 & 26 & 2 & 941 & 2,8 \\
\hline $12 / 04 / 2013$ & 79 & & 108 & 8,4 & 29,0 & & & & & & & & & & & \\
\hline $25 / 05 / 2013$ & 54 & 85 & 98 & 9,1 & 32,0 & 0,7163 & 161 & 244 & 172 & 300 & 373 & 1,4 & 65 & 12 & 1006 & 4,0 \\
\hline $21 / 06 / 2013$ & 113 & 81 & 57 & 10,8 & 29,1 & 0,7172 & 103 & 156 & 109 & 183 & 138 & 0,7 & 22 & 8 & 523 & 5,6 \\
\hline $22 / 07 / 2013$ & 164 & 142 & 43 & 8,5 & 30,6 & 0,7173 & 70 & 128 & 87 & 133 & 97 & 0,4 & 18 & 6 & 392 & 6,3 \\
\hline $18 / 08 / 2013$ & 459 & 302 & 38 & 8,1 & 29,7 & 0,7176 & 161 & 103 & 61 & 114 & 127 & 0,5 & 10 & 7 & 359 & 6,0 \\
\hline $02 / 09 / 2013$ & 1022 & 663 & 41 & 8,1 & 29,3 & 0,7172 & 163 & 104 & 54 & 109 & 146 & 0,5 & 8 & 7 & 412 & 0,0 \\
\hline $12 / 10 / 2013$ & 1472 & 1286 & 57 & 7,6 & 29,3 & 0,7170 & 143 & 126 & 62 & 156 & 230 & 0,8 & 11 & 2 & 506 & 6,2 \\
\hline $16 / 11 / 2013$ & 1312 & 1273 & 55 & 8,1 & 25,1 & 0,7175 & 150 & 139 & 73 & 149 & 218 & 0,7 & 19 & 0 & 527 & 4,7 \\
\hline $01 / 12 / 2013$ & 499 & 569 & 62 & 8,2 & 26,9 & 0,7181 & 147 & 134 & 86 & 157 & 220 & 0,7 & 14 & 5 & 529 & 6,1 \\
\hline 03/01/2014 & 384 & 242 & 81 & 7,7 & 23,9 & 0,7179 & 140 & 168 & 72 & 234 & 333 & 1,1 & 13 & 0 & 796 & 0,7 \\
\hline $19 / 02 / 2014$ & 159 & 145 & 85 & 8,5 & 23,7 & 0,7176 & 165 & 191 & 125 & 253 & 347 & 1,1 & 43 & 3 & 807 & 6,3 \\
\hline 06/03/2014 & 71 & 125 & 84 & 8,9 & 24,7 & 0,7178 & 161 & 187 & 121 & 246 & 321 & 1,1 & 41 & 1 & 749 & 7,8 \\
\hline $11 / 04 / 2014$ & 51 & 74 & 78 & 7,4 & & 0,7177 & 160 & 202 & 116 & 243 & 219 & 1,0 & 29 & 5 & 740 & 2,6 \\
\hline $14 / 05 / 2014$ & 47 & 68 & 69 & 9,0 & 28,7 & 0,7180 & 102 & 220 & 144 & 232 & 124 & 0,7 & 30 & 3 & 604 & 8,7 \\
\hline $21 / 06 / 2014$ & 64 & 52 & 59 & 8,9 & 29,2 & 0,7176 & 159 & 201 & 137 & 202 & 98 & 0,5 & 51 & 6 & 553 & 7,2 \\
\hline $23 / 07 / 2014$ & 59 & 87 & 47 & 8,8 & 29,2 & 0,7174 & 146 & 135 & 110 & 151 & 86 & 0,4 & 12 & 13 & 389 & 10,8 \\
\hline 09/08/2014 & 681 & 97 & 44 & 8,8 & 28,0 & 0,7170 & 71 & 123 & 99 & 142 & 108 & 0,5 & 38 & 16 & 497 & $-2,5$ \\
\hline 29/07/2015 & & & 88 & 7,3 & 27,2 & & & 129 & 85 & 135 & 98 & 0,5 & 21 & 8 & 411 & 0,7 \\
\hline $18 / 08 / 2015$ & & & 57 & 7,3 & 30,7 & & & 124 & 70 & 126 & 75 & 0,4 & 16 & 5 & 391 & $-2,0$ \\
\hline 18/09/2015 & & & 51 & 7,6 & 31,8 & & & 114 & 57 & 115 & 146 & 0,5 & 7 & 6 & 410 & 1,1 \\
\hline 02/10/2015 & & & 63 & 8,0 & 31,0 & & & 130 & 78 & 149 & 213 & 0,7 & 9 & 3 & 523 & 3,1 \\
\hline $23 / 11 / 2015$ & & & 74 & 7,5 & 24,3 & & & 141 & 56 & 141 & 207 & 0,7 & 8 & 0 & 478 & 5,7 \\
\hline $20 / 12 / 2015$ & & & 77 & 7,8 & 21,2 & & & 156 & 64 & 180 & 256 & 0,8 & 10 & 3 & 552 & 7,5 \\
\hline 09/01/2016 & & & 89 & 8,1 & 22,8 & & & 179 & 75 & 213 & 302 & 0,9 & 11 & 5 & 687 & 4,4 \\
\hline $18 / 02 / 2016$ & & & 97 & 8,4 & 25,0 & & & 198 & 98 & 254 & 360 & 1,1 & 13 & 2 & 767 & 7,5 \\
\hline $17 / 03 / 2016$ & & & 85 & 8,7 & 27,1 & & & 206 & 108 & 255 & 280 & 1,1 & 22 & 3 & 756 & 4,0 \\
\hline $02 / 04 / 2016$ & & & 84 & 8,8 & 24,4 & & & 216 & 116 & 260 & 237 & 1,1 & 27 & 4 & 734 & 4,0 \\
\hline $22 / 05 / 2016$ & & & 77 & 9,0 & 34,8 & & & 272 & 146 & 241 & 111 & 0,6 & 30 & 6 & 646 & 5,8 \\
\hline $18 / 06 / 2016$ & & & 75 & 9,0 & 32,6 & & & 228 & 131 & 248 & 131 & 0,8 & 33 & 8 & 647 & 3,5 \\
\hline 20/07/2016 & & & 74 & 8,3 & 31,0 & & & 129 & 85 & 170 & 129 & 0,8 & 20 & 8 & 511 & $-2,3$ \\
\hline $23 / 08 / 2016$ & & & 56 & 7,6 & 32,8 & & & 114 & 67 & 116 & 155 & 0,6 & 9 & 7 & 420 & 1,8 \\
\hline $18 / 09 / 2016$ & & & 65 & 7,2 & 31,0 & & & 184 & 94 & 146 & 213 & 0,7 & 35 & 6 & 527 & 5,7 \\
\hline $15 / 10 / 2016$ & & & 76 & 7,2 & 31,9 & & & 240 & 77 & 147 & 224 & 0,7 & 67 & 3 & 543 & 5,8 \\
\hline $11 / 11 / 2016$ & & & 62 & 9,2 & 27,8 & & & 140 & 57 & 154 & 237 & 0,8 & 8 & 4 & 554 & 1,9 \\
\hline
\end{tabular}


Table 2: Measured concentrations in Logone River monthly water samples

\begin{tabular}{|c|c|c|c|c|c|c|c|c|c|c|c|c|c|c|c|}
\hline \multirow{2}{*}{ Dates } & \multirow{2}{*}{$\begin{array}{c}\text { - calculated } \\
\left(\mathrm{m}^{3} / \mathrm{s}\right)\end{array}$} & \multirow{2}{*}{$\begin{array}{c}\text { EC } \\
\mu \mathrm{s} / \mathrm{cm}\end{array}$} & \multirow[t]{2}{*}{$\mathrm{pH}$} & \multirow{2}{*}{$\begin{array}{c}\mathrm{T} \\
{ }^{\circ} \mathrm{C}\end{array}$} & ${ }^{87} \mathrm{Sr} /{ }^{86} \mathrm{Sr}$ & $\mathrm{SiO}_{2}$ & $\mathrm{Na}^{+}$ & $\mathrm{K}^{+}$ & $\mathrm{Mg}^{2+}$ & $\mathrm{Ca}^{2+}$ & $\mathrm{Sr}^{2+}$ & $\mathrm{Cl}^{-}$ & $\mathrm{SO}_{4}^{2-}$ & $\mathrm{HCO}_{3}{ }^{-}$ & Ionic $\mathrm{B}$. \\
\hline & & & & & \multicolumn{11}{|c|}{$\mathrm{mmol} / \mathrm{L}\left(\mathrm{SiO}_{2}\right)$ and $\mu \mathrm{eq} / \mathrm{L}$ (other elements) } \\
\hline 02/01/2013 & 206 & 66 & 8,5 & 21,3 & 0,7126 & 151 & 165 & 52 & 200 & 257 & 1,4 & 10 & 2 & 630 & 3,4 \\
\hline 05/02/2013 & 135 & 64 & 8,2 & 22,7 & 0,7124 & 164 & 150 & 51 & 198 & 251 & 1,4 & 14 & 4 & 620 & 2,4 \\
\hline $11 / 03 / 2013$ & 87 & 69 & 7,9 & 26,0 & 0,7122 & 179 & 173 & 71 & 222 & 274 & 1,6 & 19 & 1 & 627 & 8,3 \\
\hline $12 / 04 / 2013$ & & 72 & 8,4 & 29,0 & 0,7122 & 185 & 214 & 99 & 223 & 274 & 1,6 & 52 & 3 & & \\
\hline $25 / 05 / 2013$ & 78 & 72 & 8,4 & 31,7 & 0,7126 & 178 & 229 & 131 & 206 & 230 & 1,4 & 66 & 4 & 696 & 6,7 \\
\hline $21 / 06 / 2013$ & 147 & 55 & 8,5 & 29,1 & 0,7123 & 130 & 146 & 65 & 146 & 165 & 1,0 & 21 & 11 & 455 & 6,9 \\
\hline $22 / 07 / 2013$ & 379 & 37 & 8,2 & 30,1 & 0,7122 & 139 & 134 & 67 & 99 & 122 & 0,6 & 26 & 8 & 384 & 4,8 \\
\hline $18 / 08 / 2013$ & 525 & 48 & 8,4 & 29,2 & 0,7126 & 146 & 125 & 57 & 123 & 162 & 0,8 & 10 & 8 & 465 & 0,3 \\
\hline 02/09/2013 & 593 & 53 & 8,1 & 29,0 & 0,7125 & 142 & 130 & 72 & 148 & 196 & 1,0 & 18 & 3 & 500 & 4,3 \\
\hline $12 / 10 / 2013$ & 744 & 55 & 7,5 & 29,8 & 0,7128 & 133 & 152 & 50 & 160 & 213 & 1,1 & 13 & 1 & 521 & 4,9 \\
\hline $16 / 11 / 2013$ & 743 & 63 & 8,7 & 26,8 & 0,7127 & 157 & 183 & 56 & 182 & 237 & 1,2 & 14 & 1 & 625 & 2,6 \\
\hline $01 / 12 / 2013$ & 451 & 72 & 7,5 & 27,3 & 0,7128 & 159 & 210 & 77 & 202 & 270 & 1,4 & 23 & 7 & 688 & 4,9 \\
\hline 03/01/2014 & 180 & 83 & 8,3 & 22,9 & 0,7126 & 170 & 193 & 81 & 197 & 255 & 1,3 & 35 & 0 & 675 & 3,6 \\
\hline $19 / 02 / 2014$ & 88 & 66 & 7,4 & 23,1 & 0,7124 & 180 & 186 & 82 & 213 & 265 & 1,5 & 44 & 0 & 652 & 6,8 \\
\hline $06 / 03 / 2014$ & 81 & 68 & 8,4 & 24,0 & 0,7123 & 175 & 164 & 69 & 207 & 252 & 1,4 & 27 & 3 & 641 & 3,9 \\
\hline $11 / 04 / 2014$ & 51 & 77 & 8,7 & 29,1 & 0,7122 & 184 & 199 & 90 & 211 & 240 & 1,5 & 36 & 5 & 649 & 6,5 \\
\hline $14 / 05 / 2014$ & 76 & 59 & 8,8 & 29,4 & 0,7122 & 160 & 177 & 87 & 172 & 188 & 1,1 & 49 & 9 & 533 & 7,9 \\
\hline $21 / 06 / 2014$ & 80 & 55 & 8,5 & 30,7 & 0,7122 & 167 & 152 & 85 & 166 & 155 & 1,0 & 38 & 6 & 505 & 5,0 \\
\hline $23 / 07 / 2014$ & 304 & 46 & 8,2 & 31,5 & 0,7123 & 146 & 128 & 101 & 115 & 146 & 0,8 & 43 & 12 & 393 & 11,0 \\
\hline 09/08/2014 & 316 & 41 & 9,1 & 28,2 & 0,7123 & 132 & 117 & 75 & 99 & 129 & 0,6 & 28 & 10 & 461 & $-4,6$ \\
\hline $29 / 07 / 2015$ & & 65 & 7,3 & 28,3 & & & 134 & 148 & 134 & 178 & 1,0 & 81 & 15 & 483 & 0,1 \\
\hline $18 / 08 / 2015$ & & 92 & 7,4 & 30,2 & & & 116 & 60 & 107 & 143 & 0,8 & 12 & 3 & 416 & $-0,5$ \\
\hline $18 / 09 / 2015$ & & 66 & 7,1 & 30,4 & & & 144 & 52 & 143 & 195 & 1,0 & 7 & 2 & 499 & 2,5 \\
\hline $02 / 10 / 2015$ & & 59 & 10,4 & 33,0 & & & 146 & 50 & 143 & 204 & 0,9 & 7 & 4 & 517 & 1,3 \\
\hline $23 / 11 / 2015$ & & 80 & 7,3 & 24,7 & & & 190 & 52 & 169 & 233 & 1,0 & 10 & 2 & 569 & 5,0 \\
\hline $20 / 12 / 2015$ & & 80 & 8,6 & 21,1 & & & 197 & 54 & 182 & 249 & 1,0 & 14 & 8 & 603 & 4,3 \\
\hline 09/01/2016 & & 74 & 8,2 & 22,5 & & & 169 & 51 & 190 & 254 & 1,2 & 12 & 6 & 589 & 4,6 \\
\hline $18 / 02 / 2016$ & & & & & & & 166 & 54 & 206 & 277 & 1,2 & 15 & 2 & 607 & 5,9 \\
\hline $17 / 03 / 2016$ & & 74 & 8,4 & 27,8 & & & 187 & 65 & 208 & 259 & 1,3 & 19 & 4 & 690 & 0,5 \\
\hline $02 / 04 / 2016$ & & 76 & 8,3 & 25,1 & & & 218 & 74 & 218 & 261 & 1,3 & 21 & 6 & 709 & 2,3 \\
\hline $22 / 05 / 2016$ & & 68 & 8,8 & 31,2 & & & 230 & 80 & 197 & 167 & 1,1 & 25 & 7 & 649 & $-0,5$ \\
\hline $18 / 06 / 2016$ & & 54 & 8,4 & 29,3 & & & 141 & 70 & 152 & 160 & 0,9 & 18 & 9 & 430 & 6,7 \\
\hline $20 / 07 / 2016$ & & 56 & 8,2 & 29,9 & & & 110 & 61 & 102 & 134 & 0,7 & 12 & 10 & 389 & $-0,6$ \\
\hline $23 / 08 / 2016$ & & 61 & 7,3 & 31,4 & & & 142 & 60 & 153 & 211 & 1,0 & 8 & 1 & 553 & 0,3 \\
\hline $18 / 09 / 2016$ & & 64 & 7,8 & 32,0 & & & 142 & 37 & 137 & 188 & 1,0 & 6 & 0 & 485 & 1,4 \\
\hline $15 / 10 / 2016$ & & 65 & 7,1 & 31,5 & & & 154 & 36 & 145 & 200 & 0,9 & 6 & 0 & 503 & 2,5 \\
\hline $11 / 11 / 2016$ & & 76 & 7,9 & 27,1 & & & 174 & 43 & 166 & 231 & 1,1 & 6 & 2 & 618 & $-1,0$ \\
\hline
\end{tabular}


Table 3: Measured concentrations in Chari-Logone River monthly water samples

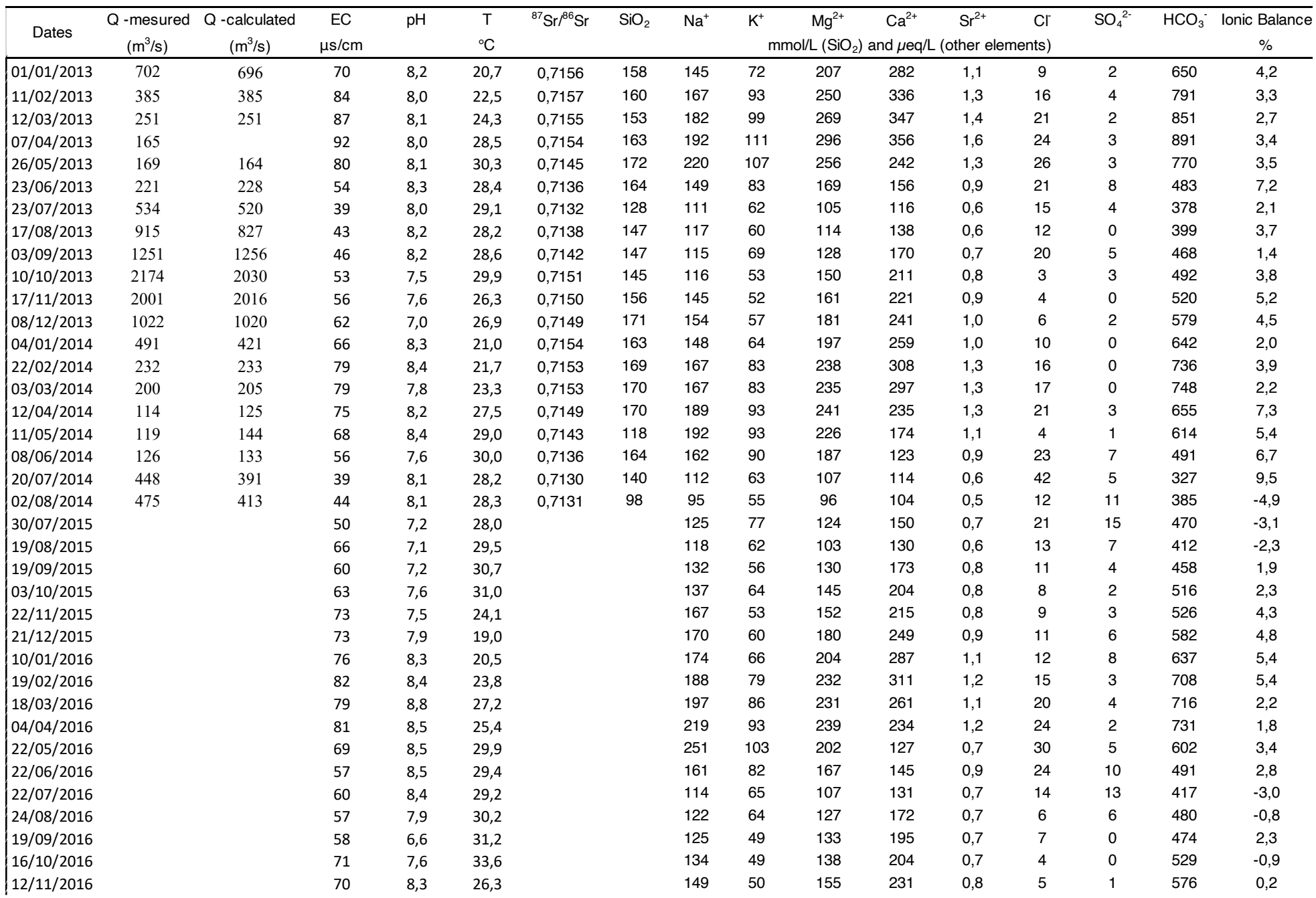


Table 4: Contribution of rainfall inputs in the Chari-Logone water.

682

683 684

685

686

687

688

689

690

691

692 Table 7: Total dissolved solid (TDS) specific fluxes $\left(\mathrm{SiO}_{2}+\mathrm{Na}+\mathrm{K}+\mathrm{Ca}+\mathrm{Mg}+\mathrm{HCO}_{3}\right)$ and 693 specific weathering rates $\left(\mathrm{SiO}_{2}+\mathrm{Na}+\mathrm{K}+\mathrm{Ca}+\mathrm{Mg}\right)$ in African rivers. Logone, Chari and 694 Chari-Logone data are obtained from this study and data for other rivers are from Meybeck and 695 Ragu (1987), Picouet et al. (2002) and Meybeck (2003).

Table 5: Synthesis of dissolved flux of water, and total dissolved solids (TDS) in the upper Niger basin (Picouet et al 2002) and in the Chari-Logone basin.

\begin{tabular}{|c|c|c|c|}
\hline Rivers & Runoff $(\mathrm{mm} / \mathrm{y})$ & TDS $(\mathrm{mg} / \mathrm{L})$ & TDS $\left(\mathrm{g} / \mathrm{m}^{2} / \mathrm{y}\right)$ \\
\hline Douna (Niger) & 70 & 45.6 & 3.2 \\
\hline Banankoro (Niger) & 331 & 41.9 & 13.9 \\
\hline Chari & 29 & 55.4 & 1.6 \\
\hline Logone & 112 & 55.5 & 6.2 \\
\hline Chari-Logone & 41 & 54 & 2.2 \\
\hline
\end{tabular}

Table 6: Ionic elemental concentration $(\mu \mathrm{eq} / \mathrm{L})$ and $(\mu \mathrm{mol} / \mathrm{L})$ for silica of the Chari-Logone basin, the Upper Niger (Picouet et al., 2002), the Congo basin and the world weighted average (Meybeck \& Ragu, 1987; Meybeck, 2003).

\begin{tabular}{|c|c|c|c|c|c|c|c|c|c|c|c|c|c|c|}
\hline \multirow{2}{*}{ Rivers } & Area & Discharge & Runoff & $\mathrm{SiO}_{2}$ & $\mathrm{Na}$ & $\mathrm{K}$ & $\mathrm{Mg}$ & $\mathrm{Ca}$ & $\mathrm{Cl}$ & $\mathrm{SO}_{4}$ & $\mathrm{HCO}_{3}$ & $\Sigma^{+}$ & $\Sigma^{-}$ & \multirow{2}{*}{ Data source } \\
\hline & $\mathrm{km}^{2}$ & $\mathrm{~km}^{3} / \mathrm{y}$ & $\mathrm{mm} / \mathrm{y}$ & $\mu \mathrm{mol} / \mathrm{L}$ & $\mu \mathrm{eq} / \mathrm{L}$ & $\mu \mathrm{eq} / \mathrm{L}$ & $\mu \mathrm{eq} / \mathrm{L}$ & $\mu \mathrm{eq} / \mathrm{L}$ & $\mu \mathrm{eq} / \mathrm{L}$ & $\mu \mathrm{eq} / \mathrm{L}$ & $\mu \mathrm{eq} / \mathrm{L}$ & $\mu \mathrm{eq} / \mathrm{L}$ & $\mu \mathrm{eq} / \mathrm{L}$ & \\
\hline $\begin{array}{c}\text { World weighted } \\
\text { average of rivers }\end{array}$ & & & & 145 & 240 & 44 & 245 & 594 & 167 & 175 & 798 & 1123 & 1140 & Meybeck 2003 \\
\hline Niger (Niamey) & 1200000 & 154 & 128 & 233 & 78 & 28 & 156 & 276 & 26 & 5 & 549 & 538 & 580 & $\begin{array}{l}\text { Meybeck et } \\
\text { Ragu } 1987 \\
\end{array}$ \\
\hline Logone (Ngueli) & 90000 & 10 & 112 & 148 & 159 & 62 & 164 & 213 & 17 & & 539 & 598 & 556 & This work \\
\hline Chari (Chagoua) & 523000 & 15 & 29 & 148 & 133 & 73 & 156 & 215 & 14 & & 524 & 577 & 538 & This work \\
\hline $\begin{array}{l}\text { Chari-Logone } \\
\text { (Douguia) }\end{array}$ & 613000 & 25 & 41 & 152 & 133 & 62 & 159 & 210 & 10 & & 523 & 564 & 533 & This work \\
\hline $\begin{array}{l}\text { Upper Niger } \\
\text { (Koulikoro) }\end{array}$ & 120000 & 33 & 273 & 203 & 124 & 45 & 86 & 114 & 23 & & 360 & 370 & 383 & $\begin{array}{l}\text { Picouet et al. } \\
2002\end{array}$ \\
\hline Congo (Zaïre) & 3700000 & 1200 & 324 & 157 & 96 & 43 & 118 & 112 & 37 & 15 & 258 & 369 & 310 & $\begin{array}{l}\text { Meybeck et } \\
\text { Ragu } 1987\end{array}$ \\
\hline
\end{tabular}




\begin{tabular}{|c|c|c|c|c|c|c|c|c|c|c|c|c|c|c|}
\hline \multirow[t]{2}{*}{ Rivers } & Area & Discharge & Runoff & $\mathrm{SiO}_{2}$ & $\mathrm{Na}$ & $\mathrm{K}$ & $\mathrm{Mg}$ & $\mathrm{Ca}$ & $\mathrm{Cl}$ & $\mathrm{SO}_{4}$ & $\mathrm{HCO}_{3}$ & $\begin{array}{l}\text { Total disolveed } \\
\text { specifique flux }\end{array}$ & \begin{tabular}{|c|} 
Specific \\
altération \\
\end{tabular} & \multirow[t]{2}{*}{ Data source } \\
\hline & $\left(\mathrm{km}^{2}\right)$ & $\left(\mathrm{km}^{3} / \mathrm{y}\right)$ & $\mathrm{mm} / \mathrm{y}$ & $\mathrm{g} / \mathrm{m}^{2} / \mathrm{y}$ & $\mathrm{g} / \mathrm{m}^{2} / \mathrm{y}$ & $\mathrm{g} / \mathrm{m}^{2} / \mathrm{y}$ & $\mathrm{g} / \mathrm{m}^{2} / \mathrm{y}$ & $\mathrm{g} / \mathrm{m}^{2} / \mathrm{y}$ & $\mathrm{g} / \mathrm{m}^{2} / \mathrm{y}$ & $\mathrm{g} / \mathrm{m}^{2} / \mathrm{y}$ & $\mathrm{g} / \mathrm{m}^{2} / \mathrm{y}$ & $\mathrm{g} / \mathrm{m}^{2} / \mathrm{y}$ & $\mathrm{g} / \mathrm{m}^{2} / \mathrm{y}$ & \\
\hline $\begin{array}{l}\text { World weighted } \\
\text { average of rivers }\end{array}$ & - & - & - & 2.98 & 1.88 & 0.6 & 1.01 & 4.04 & 2 & 2.87 & 16.54 & 31.92 & 15.38 & Meybeck 2003 \\
\hline $\begin{array}{l}\text { Upper Niger } \\
\text { (Koulikoro) }\end{array}$ & 120000 & 32.76 & 273 & 3.48 & 0.78 & 0.48 & 0.56 & 1.33 & 0.23 & - & 5.99 & 12.87 & 6.88 & $\begin{array}{l}\text { Picouet et al. } \\
2002\end{array}$ \\
\hline Congo (Zaire) & 3700000 & 1200 & 324.32 & 3.05 & 0.72 & 0.54 & 0.46 & 0.78 & 0.43 & 0.48 & 5.10 & 11.56 & 6.45 & $\begin{array}{l}\text { Meybeck et } \\
\text { Ragu } 1987\end{array}$ \\
\hline Niger (Niamey) & 1200000 & 154.1 & 128.42 & 1.80 & 0.23 & 0.14 & 0.24 & 0.76 & 0.12 & 0.06 & 4.30 & 7.65 & 3.35 & $\begin{array}{l}\text { Meybeck et } \\
\text { Ragu } 1987\end{array}$ \\
\hline Logone (Nguéli) & 90000 & 10.04 & 111.56 & 1,00 & 0.41 & 0.27 & 0.22 & 0.51 & 0.07 & 0.02 & 3.66 & 6.16 & 2.50 & This work \\
\hline $\begin{array}{c}\text { Chari-Logone } \\
\text { (Douguia) }\end{array}$ & 613000 & 25.34 & 41.34 & 0.38 & 0.13 & 0.1 & 0.08 & 0.19 & 0.01 & - & 1.32 & 2.21 & 0.89 & This work \\
\hline Chari (Chagoua) & 523000 & 15.3 & 29.25 & 0.26 & 0.09 & 0.083 & 0.06 & 0.14 & 0.01 & 0.01 & 0.93 & 1.59 & 0.66 & This work \\
\hline
\end{tabular}

